\title{
Formation of Mono- and Polynuclear Luminescent Lanthanide Complexes based on the Coordination of Pre-organized Phosphonated Pyridines
}

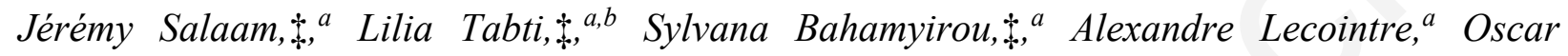
Hernandez Alba, ${ }^{c}$ Olivier Jeannin, ${ }^{d}$ Franck Camerel, ${ }^{d}$ Sarah Cianférani ${ }^{c}$ Embarek Bentouhami ${ }^{b}$ Aline M. Nonat, ${ }^{* a}$ and Loïc J. Charbonnière ${ }^{* a}$

${ }^{a}$ LIMAA, IPHC, UMR 7178, Université de Strasbourg, ECPM, 25 rue Becquerel, 67087 Strasbourg Cedex 02, France

${ }^{b}$ LCIMN Laboratory, Department of Process Engineering, Faculty of Technology, University Ferhat Abbas, 19000 Sétif, Algeria

'LSMBO, IPHC, UMR 7178, Université de Strasbourg, ECPM, 25 rue Becquerel, 67087

Strasbourg Cedex 02, France

${ }^{\mathrm{d}} \mathrm{MaCSE}$, Institut des Sciences Chimiques de Rennes (ISCR), UMR-CNRS 6226, 263 Avenue du Général Leclerc, 35042 Rennes Cedex, France

KEYWORDS : lanthanide, pyridine, phosphonate, polynuclear assemblies, luminescence

ABSTRACT. A series of polynuclear assemblies based on ligand L (1,4,7-Tris[hydrogen (6methylpyridin-2-yl)phosphonate]-1,4,7-triazacyclononane) has been developed. The coordination properties of ligand $\mathrm{L}$ with $\mathrm{Ln}^{\mathrm{IIII}}(\mathrm{Ln}=\mathrm{La}, \mathrm{Eu}, \mathrm{Tb}, \mathrm{Yb}, \mathrm{Lu})$ have been studied in water $(\mathrm{pH}=7)$ and in $\mathrm{D}_{2} \mathrm{O}(\mathrm{pD}=7)$ by $\mathrm{UV}$-absorption spectrometry, spectrofluorimetry, ${ }^{1} \mathrm{H}$ and ${ }^{31} \mathrm{P}$ NMR, DOSY, ESI-mass spectrometry and X-Ray diffraction. This nonadentate ligand forms highly stable mononuclear complexes in water and provides a very efficient shielding of the Ln cations, as emphasized by the very good luminescence properties of the $\mathrm{Yb}$ complex in $\mathrm{D}_{2} \mathrm{O}$, especially regarding its lifetime $\left(\tau_{\mathrm{D}_{2} \mathrm{O}}=10.2 \mu \mathrm{s}\right)$ and quantum yield $\left(\phi_{\mathrm{D}_{2} \mathrm{O}}=0.42 \%\right)$. In the presence of excess $\mathrm{Ln}^{\mathrm{III}}$ cation, polynuclar complexes of $\left[\left(\mathrm{LnL}_{2} \mathrm{Ln}_{\mathrm{x}}\right]\right.$ stoichiometry $(\mathrm{x}=1$ and $\mathrm{x}$ 
$=2$ ) are observed in solution. In the solid state, a dinuclear complex of La could be isolated and structurally characterized by X-ray diffraction, unraveling the presence of strong hydrogen bonding interactions between a $\mathrm{La}\left(\mathrm{H}_{2} \mathrm{O}\right){ }_{9}^{3+}$ cation and the $[\mathrm{LaL}]^{3-}$ complex.

\section{Introduction.}

Photonic up conversion (UC) is very appealing for bio-analytical assays and theranostic applications since it allows for the conversion of low energy photons in the near-infrared to visible emission. ${ }^{1}$ Although this phenomenon is usually observed in solid state materials ${ }^{2}$ and nanomaterials, ${ }^{3,4}$ a few discrete molecular systems have proven their efficiency. ${ }^{5,6,7,8,9}$ In particular, we have recently demonstrated that UC was also possible with supramolecular systems in solution at room temperature using lanthanide coordination complexes. ${ }^{78}$ In the first example, ${ }^{7}$ visible up converted emission of $\mathrm{Er}^{3+}$ was observed upon laser excitation of a sandwich $\left[\left(\mathrm{L}^{1} \mathrm{Er}\right)-\mathrm{F}-\left(\mathrm{L}^{1} \mathrm{Er}\right)\right]^{+}$assembly, in which the two Er centers were embedded in a macrocyclic DOTA derivatives ( $\mathrm{L}^{1}$, Scheme 1 ), which holds the dimeric structure by $\pi-\pi$ stacking interactions and H-bonding. ${ }^{10}$ In the second strategy, hetero polynuclear lanthanide (Ln) assemblies have been developed in order to promote $\mathrm{Yb} \rightarrow \mathrm{Tb}$ energy transfers. In this case, the tetraphosphonated octadentate ligand $\mathrm{L}^{2}$ (Scheme 1) formed highly stable mononuclear [ $\mathrm{LnL}^{2}$ ] complexes which, in the presence of excess $\mathrm{Ln}^{3+}$ salts, self-assembled into polynuclear $\left[\left(\mathrm{LnL}^{2}\right)_{2} \mathrm{Ln}\right],\left[\left(\mathrm{LnL}^{2}\right)_{2} \mathrm{Ln}_{3}\right]$ and $\left[\left(\mathrm{LnL}^{2}\right)_{2} \mathrm{Ln}_{2}\right]$ species. The assembly is driven by the strong polarization of the ligand due to the electron-rich phosphonated pendant arms. ${ }^{11}$ Such engineering offers a very good shielding of the Ln cations by the ligands and very interesting photophysical properties in water and $\mathrm{D}_{2} \mathrm{O}$. In particular, the deuterated analogues $\mathrm{YbL}^{2 \mathrm{D}}$ was used in the formation of $\left[\left(\mathrm{YbL}^{2 \mathrm{D}}\right)_{2} \mathrm{~Tb}_{\mathrm{x}}\right]$ complexes $(\mathrm{x}=1-3)$, which afforded characteristic visible $\mathrm{UC}$ emission of $\mathrm{Tb}$, upon NIR excitation of the $\mathrm{Yb}$ at $980 \mathrm{~nm}$.

In our search for new systems with improved efficiency, we turned our interest towards the development of chelates based on the 1,4,7-triazacyclononane ( $\operatorname{tacn}$ ) macrocycle appended with pyridine phosphonate units (Scheme 2). Lanthanide complexes with ligands based on tacn substituted with bipyridines, ${ }^{12}$ picolinate,${ }^{13} 8$-hydroxyquinoline ${ }^{14}$ and pyridyl phosphinate ${ }^{15,16,17}$ have proven to be very efficient in the design of highly stable mononuclear lanthanide complexes 
with very interesting photophysical properties in the solid-state, in solution and even in cellulo ${ }^{18,19}$ or on cell membranes ${ }^{20}$ and are ideal candidates for the development of biomedical imaging probes. Derivatives with two-photon antenna are also appealing for two-photon microscopy experiments in both the visible and near-infrared spectral ranges. ${ }^{21}$

Introduction of 6-phosphonated-2-methylene bridged pyridines on the nitrogen atoms is expected to lead to: the formation of two five-membered chelate rings per arm; a nonadentate coordination suited to the protection of the first coordination sphere of the Ln cations; and a $C_{3}$ symmetry with the negatively charged phosphonate functions on one side of the complexes, with the possibility to further develop electrostatic interactions in excess of Ln cations and second sphere interactions. ${ }^{11,22}$ Furthermore, phosphonated pyridines are expected to provide highly stable lanthanide complexes compared to their carboxylated analogues, ${ }^{13,23}$ and efficient sensitization of $\mathrm{Tb}^{3+}, \mathrm{Eu}^{3+}$ and, more interestingly, $\mathrm{Yb}^{3+}$.

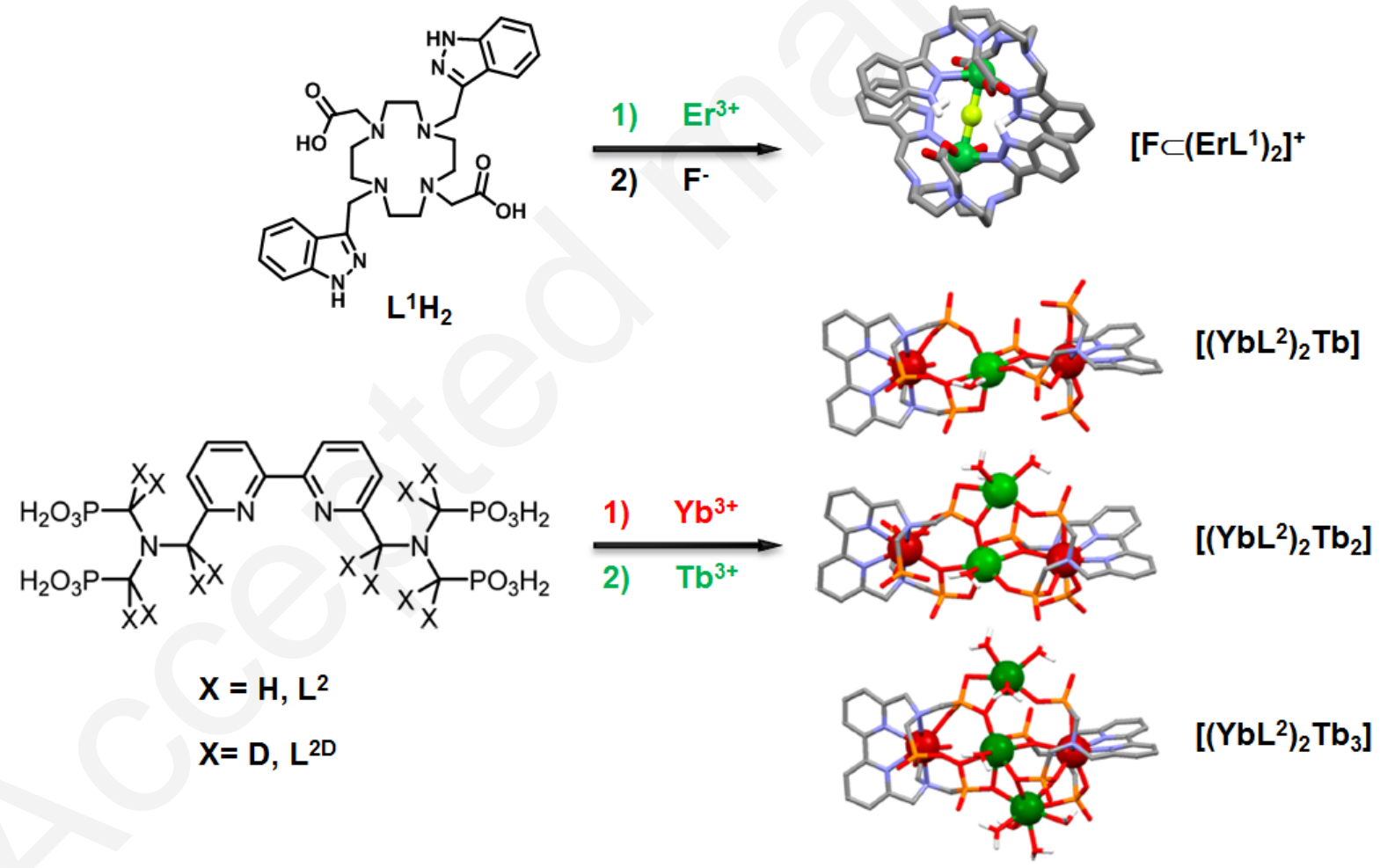

Scheme 1. Polynuclear lanthanide assemblies with ligands $\mathrm{L}^{1}, \mathrm{~L}^{2}$ and $\mathrm{L}^{2 \mathrm{D}}$. 
In this study, we report the synthesis of the new ligand L (Scheme 2 ) and a detailed analysis of its coordination properties with $\mathrm{Ln}^{3+}$ ions by $\mathrm{UV}$-absorption spectrometry, spectrofluorimetry, ${ }^{1} \mathrm{H}$ and ${ }^{31} \mathrm{P}$ NMR, DOSY, ESI-mass spectrometry and X-Ray diffraction.

\section{Experimental Section.}

General Methods. Solvents and starting materials were purchased from Aldrich, Acros and Alfa Aesar and used without further purification. Flash column chromatography was performed with silica gel (10-63 $\mu \mathrm{m}$, Macherey Nagel) or on C18 reversed phase silica (Macherey Nagel). IR spectra were recorded on a Perkin Elmer Spectrum One Spectrophotometer as solid samples and only the most significant absorption bands are given in $\mathrm{cm}^{-1}$. Elemental analysis and mass spectrometry analysis were carried out by the Service Commun d'Analyses of the University of Strasbourg. ${ }^{1} \mathrm{H},{ }^{31} \mathrm{P}$ and ${ }^{13} \mathrm{C}$ NMR spectra and 2D COSY, NOESY, HSQC, and HMBC experiments were recorded on Avance 300 and Avance 400 spectrometers operating at 300 and $400 \mathrm{MHz}$ for ${ }^{1} \mathrm{H}$, respectively. Chemical shifts are reported in ppm, with residual protonated solvent as internal reference. ${ }^{24}$ When unspecified, coupling constants refer to $\mathrm{H}-\mathrm{H}$ coupling. The given $\mathrm{pH}$ values are corrected for the deuterium isotopic effects $(\mathrm{pD}=$ apparent $\mathrm{pH}+0.4){ }^{25}$

Synthesis of diethyl (6-(chloromethyl)pyridin-2-yl)phosphonate 3: In a $250 \mathrm{~mL}$ round bottom flask, 2-(chloromethyl)pyridine-1-oxide ${ }^{26}(4.00 \mathrm{~g}, 27.9 \mathrm{mmol})$ was dissolved in dichloromethane $(100 \mathrm{~mL})$ under an argon atmosphere. Ethyl chloroformate $(8.0 \mathrm{~mL}, 83.7 \mathrm{mmol})$ was added and the solution was stirred at r.t. for $30 \mathrm{~min}$. Triethyl phosphite $(14.8 \mathrm{~mL}, 86.3 \mathrm{mmol})$ was added dropwise, and the resulting solution was stirred at r.t. during $2 \mathrm{hrs}$. The resulting mixture was washed with saturated $\mathrm{NaHCO}_{3}$, water and brine, dried over $\mathrm{Na}_{2} \mathrm{SO}_{4}$, filtered and concentrated to dryness under vacuum. Impurities were removed by distillation under reduced pressure. Purification of the crude product was performed by column chromatography over silica gel $\left(\mathrm{CH}_{2} \mathrm{Cl}_{2} / \mathrm{MeOH}\right.$ gradient from 100:0 to $\left.97: 3\right)$ yielding $3(4.17 \mathrm{~g}, 57 \%)$ as an oil. ${ }^{1} \mathrm{H}$ NMR $\left(\mathrm{CDCl}_{3}, 400 \mathrm{MHz}\right): \delta 7.78(\mathrm{~m}, 2 \mathrm{H}), 7.57\left(\mathrm{td}, J_{1}=7.7 \mathrm{~Hz}, J_{2}=1.6 \mathrm{~Hz}, 1 \mathrm{H}\right), 4.65(\mathrm{~s}, 2 \mathrm{H}), 4.15(\mathrm{~m}$, 4H), 1.27 (t, $J=7.2 \mathrm{~Hz}, 6 \mathrm{H})$ ppm. ${ }^{13} \mathrm{C}$ NMR $\left(\mathrm{CDCl}_{3}, 75 \mathrm{MHz}\right): \delta 157.7$ (d, $\left.J=22.8 \mathrm{~Hz}\right), 151.6$ $(\mathrm{d}, J=226.7 \mathrm{~Hz}), 137.2$ (d, $J=12.1 \mathrm{~Hz}), 127.2$ (d, $J=24.9 \mathrm{~Hz}), 125.2(\mathrm{~d}, J=3.6 \mathrm{~Hz}), 63.2(\mathrm{~d}, J$ $=5.9 \mathrm{~Hz}), 46.4,16.4(\mathrm{~d}, J=5.9 \mathrm{~Hz}) \mathrm{ppm} .{ }^{31} \mathrm{P} \mathrm{NMR}\left(\mathrm{CDCl}_{3}, 162 \mathrm{MHz}\right): \delta 10.0 \mathrm{ppm} . \mathrm{IR}\left(\mathrm{cm}^{-1}\right.$, ATR): $v 2983(\mathrm{~m}), 1582(\mathrm{~m}), 1478(\mathrm{w}), 1447(\mathrm{~m}), 1392(\mathrm{w}), 1249\left(\mathrm{~s}, v_{\mathrm{P}=0}\right), 1182(\mathrm{~m}), 1016(\mathrm{~s})$, 
961 (s), $881(\mathrm{~m}) . \mathrm{ESI}^{+} / \mathrm{MS}: m / z=270.064\left([\mathrm{M}+\mathrm{Li}]^{+}, 100 \%\right)$. Anal. Calcd. for $\mathrm{C}_{10} \mathrm{H}_{15} \mathrm{ClNO}_{3} \mathrm{P}: \mathrm{C}$, 45.55; H, 5.73; N, 5.31. Found: C, 44.91; H, 5.71; N, 5.28.

Synthesis of compound 4: A schlenk tube containing 3 (2.00 g, $7.6 \mathrm{mmol})$, TACN (325 mg, 2.5 mmol), and flame dried $\mathrm{K}_{2} \mathrm{CO}_{3}(1.75 \mathrm{~g}, 12.7 \mathrm{mmol})$, dissolved in anhydrous $\mathrm{CH}_{3} \mathrm{CN}$, was stirred for $16 \mathrm{hrs}$ at $50^{\circ} \mathrm{C}$. The remaining $\mathrm{K}_{2} \mathrm{CO}_{3}$ was removed by filtration and the solvent was removed under reduced pressure. The resulting residue was dissolved in dichloromethane, washed with water and brine, dried over $\mathrm{Na}_{2} \mathrm{SO}_{4}$, filtered and concentrated to dryness under vacuum. Purification of the crude product was performed by column chromatography over alumina $\left(\mathrm{CH}_{2} \mathrm{Cl}_{2} / \mathrm{MeOH}\right.$ gradient from 100:00 to 95:5) yielding compound 4 (1.18 g, 56\%) as pale yellow oil. ${ }^{1} \mathrm{H} \mathrm{NMR}\left(\mathrm{CDCl}_{3}, 500 \mathrm{MHz}\right): \delta 7.74(\mathrm{t}, J=6.8 \mathrm{~Hz}, 3 \mathrm{H}), 7.68\left(\mathrm{td}, J_{1}=7.6 \mathrm{~Hz}, J_{2}=5.9 \mathrm{~Hz}\right.$, $3 \mathrm{H}), 7.60(\mathrm{~d}, J=7.6 \mathrm{~Hz}, 3 \mathrm{H}), 4.23-4.11(\mathrm{~m}, 12 \mathrm{H}), 3.89(\mathrm{~s}, 6 \mathrm{H}), 2.85(\mathrm{~s}, 12 \mathrm{H}), 1.28(\mathrm{t}, J=7.1$ $\mathrm{Hz}, 18 \mathrm{H})$ ppm. ${ }^{13} \mathrm{C} \mathrm{NMR}\left(\mathrm{CDCl}_{3}, 125 \mathrm{MHz}\right): \delta 161.6(\mathrm{br}), 151.3$ (d, $\left.J=227.5 \mathrm{~Hz}\right), 136.5(\mathrm{~d}, J=$ $12.3 \mathrm{~Hz}), 126.5(\mathrm{~d}, J=25.4 \mathrm{~Hz}), 125.7,64.4,63.0(\mathrm{~d}, J=5.9 \mathrm{~Hz}), 55.9,16.5(\mathrm{~d}, J=5.9 \mathrm{~Hz})$ ppm. ${ }^{31} \mathrm{P}$ NMR $\left(\mathrm{CDCl}_{3}, 202 \mathrm{MHz}\right): \delta 11.0$ ppm. IR (cm $\left.{ }^{-1}, \mathrm{ATR}\right): v 2982(\mathrm{w}), 2906(\mathrm{w}), 1672$ (w), 1582 (w), 1443 (m), 1391 (w), 1367 (w), 1254 (s, vp=O), 1163 (m), 1016 (s), 961 (s), 790 (m), $760(\mathrm{~m}), 564(\mathrm{~m}), 532(\mathrm{~m}) . \mathrm{ESI}^{+} / \mathrm{MS}: m / z=811.34\left([\mathrm{M}+\mathrm{H}]^{+}, 100 \%\right)$. Anal. Calcd. for $\mathrm{C}_{36} \mathrm{H}_{57} \mathrm{~N}_{6} \mathrm{O}_{9} \mathrm{P}_{3} \bullet \mathrm{H}_{2} \mathrm{O}: \mathrm{C}, 52.17 ; \mathrm{H}, 7.15 ; \mathrm{N}, 10.14$. Found: C, 51.79; H, 6.96; N, 9.64.

Synthesis of ligand L. Compound 4 (200 mg, $0.24 \mathrm{mmol})$ was dissolved in $6 \mathrm{~N} \mathrm{HCl}$ solution (30 $\mathrm{mL}$ ) and was refluxed during $16 \mathrm{hrs}$. The solvent was removed under vacuum and ligand $\mathbf{L}$ (175 mg, $0.20 \mathrm{mmol}, 90 \%$ ) was obtained as a white powder. ${ }^{1} \mathrm{H} \mathrm{NMR}\left(\mathrm{D}_{2} \mathrm{O}, 500 \mathrm{MHz}\right): \delta 8.21\left(\mathrm{td}, J_{1}\right.$ $\left.=7.9 \mathrm{~Hz}, J_{2}=3.7 \mathrm{~Hz}, 3 \mathrm{H}\right), 7.96(\mathrm{t}, J=7.4 \mathrm{~Hz}, 3 \mathrm{H}), 7.79(\mathrm{~d}, J=8.0 \mathrm{~Hz}, 3 \mathrm{H}), 4.51(\mathrm{~s}, 6 \mathrm{H}), 3.27$ (s, $12 \mathrm{H})$ ppm. ${ }^{13} \mathrm{C}$ NMR $\left(\mathrm{D}_{2} \mathrm{O}, 125 \mathrm{MHz}\right): \delta 153.1$ (d, $\left.J=194.4 \mathrm{~Hz}\right), 152.7$ (d, $\left.J=13.7 \mathrm{~Hz}\right)$, 143.3 (d, $J=10.0 \mathrm{~Hz}), 127.8$ (d, $J=16.4 \mathrm{~Hz}), 127.5,57.5,50.1$ ppm. ${ }^{31} \mathrm{P}$ NMR $\left(\mathrm{D}_{2} \mathrm{O}, 202 \mathrm{MHz}\right)$ : $\delta 1.84$ ppm. IR (cm ${ }^{-1}$, ATR): $v 2638$ (m, br), $1628(\mathrm{w}), 1403(\mathrm{w}), 1147$ (m), 925 (s), $812(\mathrm{~m}), 692$ $(\mathrm{m}), \quad 532$ (s). $\quad \mathrm{ESI}^{+} / \mathrm{MS}: \quad m / z=643.15\left([\mathrm{M}+\mathrm{H}]^{+}, \quad 100 \%\right)$. Anal. Calcd. for $\mathrm{C}_{24} \mathrm{H}_{33} \mathrm{~N}_{6} \mathrm{O}_{9} \mathrm{P}_{3} \cdot 3 \mathrm{HCl} \cdot 3 \mathrm{H}_{2} \mathrm{O}: \mathrm{C}, 35.77 ; \mathrm{H}, 5.25 ; \mathrm{N}, 10.43$. Found: C, 35.38; H, 5.08; N, 10.45 .

Synthesis and characterization of the $\mathrm{Ln}^{3+}$ complexes. General method. In order to control the strict 1:1 stoechiometry of the complexes and to avoid excess of Ln cations in the formed complexes, the complexes were prepared in $\mathrm{D}_{2} \mathrm{O}$ and the formations of the complexes were 
monitored by ${ }^{1} \mathrm{H}-\mathrm{NMR}$. To a solution of ligand $\mathrm{L}$ ( $\mathrm{ca} 40 \mathrm{mg}$ ) in $\mathrm{D}_{2} \mathrm{O}$, a volume corresponding to half an equivalent of $\mathrm{Ln}$ cation of a stock solution of $\mathrm{LnCl}_{3} \cdot \mathrm{xH}_{2} \mathrm{O}$ in $\mathrm{D}_{2} \mathrm{O}$ was added. The ${ }^{1} \mathrm{H}$ NMR spectrum of the solution was recorded and the exact volume corresponding to the missing half equivalent was added. A $0.1 \mathrm{M} \mathrm{NaOD}$ solution was added to raise the $\mathrm{pD}$ to 7 and the complete formation of the mononuclear complex was verified by ${ }^{1} \mathrm{H} \mathrm{NMR}$. Addition of $\mathrm{HCl}$ until $\mathrm{pH}=3.5$ resulted in the formation of a precipitate. Complete precipitation was achieved by addition of a THF/methanol mixture. The precipitate was isolated by centrifugation, dried under reduced pressure $\left(2 \mathrm{~h}, 40^{\circ} \mathrm{C}\right)$ and purified (except for the $\mathrm{Lu}$ and $\mathrm{Tb}$ complexes ) by flash column chromatography on reverse phase $\mathrm{C} 18$ column $\left(\mathrm{H}_{2} \mathrm{O} / \mathrm{MeOH} / \mathrm{TFA} 0.1 \%\right)$ to give [LnL] complex as a white powder.

[EuL]. From $456 \mu \mathrm{L}$ of $\mathrm{EuCl}_{3} \cdot 6 \mathrm{H}_{2} \mathrm{O}$ at $0.11 \mathrm{M}(50 \mathrm{mmol})$ and $40.0 \mathrm{mg}(50 \mathrm{mmol})$ of ligand $\mathrm{L}$, one obtains $35.1 \mathrm{mg}$ of $[\mathrm{EuL}] \cdot\left(\mathrm{CF}_{3} \mathrm{CO}_{2} \mathrm{H}\right)_{2} \cdot 2 \mathrm{H}_{2} \mathrm{O}(70 \%)$. ${ }^{1} \mathrm{H}$ NMR $\left(\mathrm{D}_{2} \mathrm{O}, \mathrm{pD}=7.0,400 \mathrm{MHz}\right): \delta$ 8.42 (s, br, 3H), 7.53 (s, 3H), 7.30 (tr, br, 3H), 6.03 (d, br, $\left.{ }^{3} J=7.0 \mathrm{~Hz}\right), 3.72$ (s, br, 3H), 1.03 (s, br, 3H), -1.72 (s, br, 3H), -2.82 (s, br, 3H), -5.61 (s, br, 3H) ppm. ESI ${ }^{+} / \mathrm{MS}: m / z=791.1$ $\left([(\mathrm{EuL})+\mathrm{H}]^{+}, 85 \%\right), 793.1\left([(\mathrm{EuL})+\mathrm{H}]^{+}, 100 \%\right) .{ }^{19} \mathrm{~F}$ NMR $\left(\mathrm{D}_{2} \mathrm{O}, 282 \mathrm{MHz}\right): \delta-75.60(\mathrm{~s})$. Anal. Calcd. for $\mathrm{C}_{24} \mathrm{H}_{30} \mathrm{EuN}_{6} \mathrm{O}_{9} \mathrm{P}_{3} \cdot 2 \mathrm{TFA} \cdot 2 \mathrm{H}_{2} \mathrm{O}\left(\mathrm{C}_{28} \mathrm{H}_{36} \mathrm{EuF}_{6} \mathrm{~N}_{6} \mathrm{O}_{15} \mathrm{P}_{3}\right): \mathrm{C}, 31.86 ; \mathrm{H}, 3.44 ; \mathrm{N}, 7.96$. Found: C, 31.67; H, 3.54; N, 8.21.

[YbL]. From $415 \mu \mathrm{L}(50 \mathrm{mmol})$ of a $0.11 \mathrm{M}$ solution of $\mathrm{YbCl}_{3} \cdot 6 \mathrm{H}_{2} \mathrm{O}$ and $40.0 \mathrm{mg}(50 \mathrm{mmol})$ of ligand $\mathrm{L}$, one obtains $22.6 \mathrm{mg}(32 \%)$ of $[\mathrm{YbL}] \cdot 5\left(\mathrm{CF}_{3} \mathrm{CO}_{2} \mathrm{H}\right) \cdot 2 \mathrm{H}_{2} \mathrm{O} .{ }^{1} \mathrm{H}$ NMR $\left(\mathrm{D}_{2} \mathrm{O}, 300 \mathrm{MHz}\right.$, $\mathrm{pD}=7.87): \delta 23.00(\mathrm{~s}, \mathrm{br}, 3 \mathrm{H}), 11.69(\mathrm{~s}, \mathrm{br}, 3 \mathrm{H}), 10.94(\mathrm{~s}, \mathrm{br}, 6 \mathrm{H}), 5.90(\mathrm{~s}, \mathrm{br}, 6 \mathrm{H}),-5.45$ (s, br, 3H), -6.60 (s, br, 3H), -17.18 (s, br, 3H) ppm. ${ }^{19} \mathrm{~F}$ NMR ( $\left.\mathrm{D}_{2} \mathrm{O}, 282 \mathrm{MHz}\right): \delta-75.60$ (s). Anal. Calcd. for $\mathrm{C}_{24} \mathrm{H}_{30} \mathrm{~N}_{6} \mathrm{O}_{9} \mathrm{P}_{3} \mathrm{Yb} \cdot 5 \mathrm{TFA} \cdot 2 \mathrm{H}_{2} \mathrm{O}\left(\mathrm{C}_{34} \mathrm{H}_{39} \mathrm{~F}_{15} \mathrm{~N}_{6} \mathrm{O}_{21} \mathrm{P}_{3} \mathrm{Yb}\right)$ : C, 28.79; H, 2.77; N, 5.92. Found: C, 29.20; H, 3.08; N, 5.79. $\mathrm{ESI}^{+} / \mathrm{MS}: m / z=814.1\left([(\mathrm{YbL})+\mathrm{H}]^{+}, 100 \%\right)$.

[LuL]. From $944 \mu \mathrm{L}(51 \mathrm{mmol})$ of a $0.054 \mathrm{M}$ solution of $\mathrm{LuCl}_{3} .6 \mathrm{H}_{2} \mathrm{O}$ and $40.9 \mathrm{mg}(51 \mathrm{mmol})$ of ligand $\mathrm{L}$, one obtains $27.9 \mathrm{mg}(44 \%)$ of [LuL]. ${ }^{1} \mathrm{H} \mathrm{NMR}\left(\mathrm{D}_{2} \mathrm{O}, 400 \mathrm{MHz}, \mathrm{pD}=6.3\right): \delta 7.98$ (td, $\left.{ }^{3} J_{H-H}=7.6 \mathrm{~Hz},{ }^{4} J_{P-H}=3.7 \mathrm{~Hz}, 3 \mathrm{H}, \mathrm{H}_{4 \mathrm{Pyr}}\right), 7.73\left(\mathrm{t},{ }^{3} J_{H-H}=6.5 \mathrm{~Hz},{ }^{3} J_{P-H}=6.5 \mathrm{~Hz}, 3 \mathrm{H}, \mathrm{H}_{2 \text { Pуг }}\right), 7.52$ $\left(\mathrm{d},{ }^{3} J_{H-H}=7.5 \mathrm{~Hz}, 3 \mathrm{H}, \mathrm{H}_{5 \mathrm{pyr}}\right), 4.25$ (AB system, $\delta_{\mathrm{A}}=4.70 \mathrm{ppm}, \delta_{\mathrm{B}}=3.81 \mathrm{ppm}, J_{A B}=13.9 \mathrm{~Hz}$, $6 \mathrm{H}), 3.37(\mathrm{td}, J=12.8 \mathrm{~Hz}, J=4.2 \mathrm{~Hz}, 3 \mathrm{H}), 2.75(\mathrm{dd}, J=16.2 \mathrm{~Hz}, J=5.2 \mathrm{~Hz}, 3 \mathrm{H}), 2.41(\mathrm{dd}, J=$ $12.9 \mathrm{~Hz}, J=4.4 \mathrm{~Hz}, 3 \mathrm{H}), 2.27(\mathrm{td}, J=13.8 \mathrm{~Hz}, J=5.0 \mathrm{~Hz}, 3 \mathrm{H}) \mathrm{ppm} . \mathrm{ESI}^{+} / \mathrm{MS}: m / z=814.1$ 
$\left([\mathrm{LuL}-2 \mathrm{H}]^{+}, 100 \%\right) ; 837.1\left([\mathrm{LuL}-3 \mathrm{H}+\mathrm{Na}]^{+}, 40 \%\right) .{ }^{31} \mathrm{P}$ NMR $\left(\mathrm{D}_{2} \mathrm{O}, 202 \mathrm{MHz}, \mathrm{pD}=6.3\right): \delta 12.86$ ppm. Anal. Calcd. for $\mathrm{C}_{24} \mathrm{H}_{30} \mathrm{~N}_{6} \mathrm{O}_{9} \mathrm{P}_{3} \mathrm{Lu} \cdot 7 \mathrm{NaCl} \cdot 4 \mathrm{H}_{2} \mathrm{O}\left(\mathrm{C}_{24} \mathrm{H}_{38} \mathrm{Cl}_{7} \mathrm{LuN}_{6} \mathrm{Na}_{7} \mathrm{O}_{13} \mathrm{P}_{3}\right): \mathrm{C}, 22.25 ; \mathrm{H}$, 2.96; N, 6.49. Found: C, 22.04; H, 3.05; N, 6.32.

[TbL]. $46.2 \mathrm{mg}(123.7 \mathrm{mmol})$ of $\mathrm{TbCl}_{3} .6 \mathrm{H}_{2} \mathrm{O}$ in $\mathrm{D}_{2} \mathrm{O}(2 \mathrm{~mL})$ were added to $97.9 \mathrm{mg}(122 \mathrm{mmol})$ of ligand. ${ }^{1} \mathrm{H}$ NMR ( $\mathrm{D}_{2} \mathrm{O}, 400 \mathrm{MHz}, \mathrm{pD}=7.96$ ): $\delta 84.56$ (s, br, $3 \mathrm{H}$ ), 32.84 (s, br, $3 \mathrm{H}$ ), 17.11 (s, br, 3 H), -5.48 (s, br, 3 H), -8.40 (s, br, 3 H), -9.77 (s, br, 6 H), -14.53 (s, br, 3 H), -70.05 (s, br, $3 \mathrm{H}) .{ }^{31} \mathrm{P}$ NMR $\left(\mathrm{D}_{2} \mathrm{O}, 202 \mathrm{MHz}, \mathrm{pD}=7.96\right): \delta-94.37(\mathrm{br}) . \mathrm{ESI}^{-} / \mathrm{MS}: m / z=398.02\left([\mathrm{M}-2 \mathrm{H}]^{2-}\right.$, $100 \%) ; \quad 797.04 \quad\left([\mathrm{M}-\mathrm{H}]^{-}, \quad 74 \%\right)$. Anal. Calcd. for $\mathrm{C}_{24} \mathrm{H}_{30} \mathrm{~N}_{6} \mathrm{O}_{9} \mathrm{P}_{3} \mathrm{~Tb} \cdot 3 \mathrm{NaCl} \cdot 7 \mathrm{H}_{2} \mathrm{O}$ $\left(\mathrm{C}_{24} \mathrm{H}_{44} \mathrm{Cl}_{3} \mathrm{TbN}_{6} \mathrm{Na}_{3} \mathrm{O}_{16} \mathrm{P}_{3}\right): \mathrm{C}, 26.65 ; \mathrm{H}, 3.91 ; \mathrm{N}, 7.77$. Found: C, 26.68; H, 4.10; N, 7.78.

X-ray Crystallography. Crystals suitable for X-ray diffraction were obtained by slow evaporation of aqueous solutions. The crystals were placed in oil, and a single crystal was selected, mounted on a nylon loop and placed in a low-temperature $\mathrm{N}_{2}$ stream. X-Ray diffraction data collection was carried out on a Bruker APEX II Kappa-CCD or a D8 VENTURE Bruker AXS diffractometer equipped with an Oxford Cryosystem liquid $\mathrm{N}_{2}$ device, using Mo-K $\alpha$ radiation $(\lambda=0.71073 \AA)$ at $150(2) \mathrm{K}$ (Centre de diffractométrie X, Université de Rennes 1, France). The Bruker SMART program was used to refine the values of the cell parameters. Data reduction and correction absorption (SADABS) were carried out using the Bruker SAINT programs. The structures were solved by direct methods using the SIR97 program $^{27}$ and then refined with full-matrix least-squares methods based on $\mathrm{F}^{2}$ (SHELX-97) ${ }^{28}$ with the aid of the WINGX program. ${ }^{29}$ All non-hydrogen atoms were refined with anisotropic displacement parameters. For the $[\mathrm{EuL}]$ structure, the $\mathrm{H}$ atoms of phosphonate groups have been found in the electron density maps and refined as idealized hydroxyl group with torsion from electron density (AFIX 147 instruction). $\mathrm{H}$ atoms on the less agitated water molecules have been found in electron density map and refined with restraints on O...H (DFIX 0.84 0.01) and H...H (DANG 1.340 .01 ). The four most agitated water molecules were squeezed. Their contribution to the calculated structure factors was estimated following the BYPASS algorithm, ${ }^{30}$ implemented as the SQUEEZE option in PLATON. ${ }^{31}$ The new data set, free of the four highly agitated water molecules contribution, was then used in the final refinement. For the $[\mathrm{LaL}]$ structure, $\mathrm{H}$ atoms on water molecules are found in electron density map and refined with restraints on $\mathrm{O} \ldots \mathrm{H}$ (DFIX 0.840 .01 ) and H...H (DANG 1.34 0.01). All the other hydrogen atoms localized on 
carbon atoms were included in their calculated positions. Crystallographic data for structural analysis of the mononuclear $\mathrm{Eu}$ and of the La dinuclear complexes have been deposited with the Cambridge Crystallographic Data Centre under CCDC nos. 1589355 and 1589357, respectively. Copies of this information is available free of charge from the Web site (www.ccdc.cam.ac.uk).

\section{Physico-chemical and spectrophotometric studies.}

Materials. Distilled water was purified by passing through a mixed bed of ion-exchanger (Bioblock Scientific R3-83002, M3-83006) and activated carbon (Bioblock Scientific ORC83005). All the stock solutions were prepared by weighing solid products using an AG 245 Mettler Toledo analytical balance (precision $0.01 \mathrm{mg}$ ). Metal cation solutions were prepared from their chloride $\left(\mathrm{LaCl}_{3} .7 \mathrm{H}_{2} \mathrm{O}, \mathrm{EuCl}_{3} .6 \mathrm{H}_{2} \mathrm{O}, \mathrm{TbCl}_{3} .6 \mathrm{H}_{2} \mathrm{O}, \mathrm{YbCl}_{3} .6 \mathrm{H}_{2} \mathrm{O}, \mathrm{LuCl}_{3} .6 \mathrm{H}_{2} \mathrm{O}, 99.9 \%\right.$, Sigma-Aldrich) and their concentrations were determined by colorimetric titrations with EDTA $\left(10^{-2} \mathrm{M}\right.$, Merck, Titriplex III) according to standard procedures, using xylenol orange as indicator. ${ }^{30}$ Sodium hydroxyde $(\mathrm{NaOH})$ and hydrochloric acid $(\mathrm{HCl})$ were used to adjust $\mathrm{pH}$ during titrations. All the experiments described were repeated at least two times. Spectroscopic measurements were performed with $10 \times 10 \mathrm{~mm}^{2}$ quartz suprasil certified cells (Helma Analytics). UV/vis absorption spectra were recorded on a Perkin Elmer lambda 950 or on a Specord spectrometer from Jena Analytics. Steady state emission spectra were recorded on an Edinburgh Instrument FLP920 spectrometer working with a continuous 450W Xe Lamp and a red sensitive R928 photomultiplier from Hamamatsu in Pelletier housing for visible detection (230 to $900 \mathrm{~nm}$ ) or a Hamamatsu R5 509-72 photomultiplier for the Vis-NIR part. All spectra were corrected for the instrumental functions. For emission spectra upon UV excitation, a $399 \mathrm{~nm}$ cutoff filter was used to eliminate second order artifacts. Phosphorescence lifetimes were measured on the same instrument working in the Multi-Channel Spectroscopy (MCS) mode, using a Xenon flash lamp as the excitation source. For short $\mu$ s lifetimes, the intensity decay was corrected from the lamp intensity decay profile using a scattering solution of Ludox in water. Luminescence quantum yields were measured according to conventional procedures, ${ }^{31}$ with optically diluted solutions (optical density $<0.05)$, using $\left[\mathrm{Ru}(\text { bipy })_{3} \mathrm{Cl}_{3}\right]$ in water $(\Phi=0.04)^{32}$ as reference for $\mathrm{Eu}$, a bipyridine $\mathrm{Tb}$ complex, $\left[\mathrm{TbL}\left(\mathrm{H}_{2} \mathrm{O}\right)\right]$ in water $(\Phi=0.31)^{33}$ as reference for $\mathrm{Tb}$, and cardiogreen (IR125) in $\mathrm{MeOH}(\Phi=0.078)$ for $\mathrm{Yb}^{34}$ The errors are estimated to $10 \%$ on the lifetimes and $15 \%$ on the luminescence quantum yields. 
${ }^{1} \mathbf{H}$ and ${ }^{31} \mathbf{P}$ NMR titrations. Aliquots of a stock solution of the lanthanide trichloride salt in $\mathrm{D}_{2} \mathrm{O}$ $\left(\left[\mathrm{Lu}^{3+}\right]=5.4 \times 10^{-2} \mathrm{M},\left[\mathrm{Yb}^{3+}\right]=0.1 \mathrm{M},\left[\mathrm{Eu}^{3+}\right]=0.1 \mathrm{M}\right)$ were added to a ligand solution in $\mathrm{D}_{2} \mathrm{O}$ at $\mathrm{pD}=7\left([\mathrm{~L}]=17 \mathrm{mM}\right.$ for $\mathrm{Lu}^{3+},[\mathrm{L}]=6.9 \mathrm{mM}$ for $\mathrm{Yb}^{3+}$ and $110 \mathrm{mM}$ for $\left.\mathrm{Eu}^{3+}\right)$. After each addition, $\mathrm{pD}$ was adjusted to a value of 7.0 with $0.1 \mathrm{M} \mathrm{NaOD}$ solution in $\mathrm{D}_{2} \mathrm{O}$. Changes after addition from 0 to 2.5 equivalents of metal were monitored by recording the ${ }^{1} \mathrm{H}(400 \mathrm{MHz})$ and ${ }^{31} \mathrm{P}$ spectra (162 MHz), respectively. In the case of $\mathrm{Lu}^{3+}$, diffusion spectroscopy (DOSY) NMR studies were carried out in order to measure the diffusion coefficient of the species present in solution. To this aim, a second titration was performed by adding $0,0.5,1.2,1.6$ and 2.0 equivalents of a $\mathrm{LuCl}_{3} .6 \mathrm{H}_{2} \mathrm{O}$ solution in $\mathrm{D}_{2} \mathrm{O}\left(5.4 \times 10^{-2} \mathrm{M}\right)$ to a ligand stock solution $(0.021 \mathrm{M})$ at $\mathrm{pD}=7.0$.

Mass spectrometry and ion mobility mass spectrometry. Mass spectrometry and ion mobility experiments were performed on a QTOF mass spectrometer (Synapt G2, Waters, Manchester, UK), coupled to an automated chip-based nanoelectrospray device (Triversa Nanomate, Advion, Ithaca, U.S.A.) operating in the positive ion mode. The sampling cone and the extraction cone voltages were set to $40 \mathrm{~V}$ and $4 \mathrm{~V}$, respectively. Ions were efficiently thermalized with a constant trapping voltage of $7 \mathrm{~V}$ and subsequently transferred into the TOF analyzer.

Ion mobility (IM) experiments were performed under a constant pressure of $\mathrm{N}_{2}$ of 3.3 mbar in the traveling wave IM cell. A constant pressure of $1.4 \times 10^{-3} \mathrm{mbar}$ of He was applied to focus the ions prior to IM separation. The IM wave height and velocity were $40 \mathrm{~V}$ and $950 \mathrm{~m} / \mathrm{s}$, respectively. Transfer collision energy was set to $10 \mathrm{~V}$ to extract the ions from the IM cell to the TOF analyzer.

Spectrophotometric and spectrofluorimetric titrations. Titrations were performed by stepwise addition of microvolumes of a $10^{-3} \mathrm{M}$ stock solution of the lanthanide salt $\left(\mathrm{LnCl}_{3} \cdot 6 \mathrm{H}_{2} \mathrm{O}\right.$, $\mathrm{Ln}=\mathrm{Eu}, \mathrm{Tb}, \mathrm{Yb})$ at $\mathrm{pH} 7.0$ (Tris- $\mathrm{HCl} 0.1 \mathrm{M})$ to $2 \mathrm{~mL}$ of ligand solution $\left(5 \times 10^{-5} \mathrm{M}\right.$ in Tris- $\mathrm{HCl}$ $0.1 \mathrm{M}$ at $\mathrm{pH}=7.0$ ) in $1 \mathrm{~cm}$ quartz suprasil cell. After each addition, the UV-Visible absorption spectra were recorded, together with the emission spectra upon excitation of the ligand at $\lambda_{\mathrm{ex}}=$ $267 \mathrm{~nm}$. The software Hypspec V1.1.33 was used to determine the coordination model and calculate the stability constants $(\log \beta)$ of the formed species. ${ }^{35}$

\section{Results and Discussion.}

\section{Synthesis of ligand $L$.}


Ligand L was obtained in four synthetic steps starting from the commercially available 2chloromethylpyridine $\mathbf{1}$ as depicted in Scheme 2.

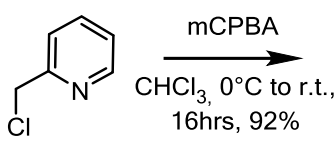

1

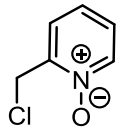

2

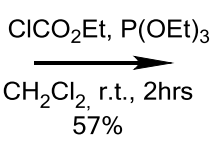

$57 \%$

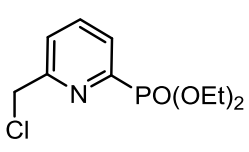

3

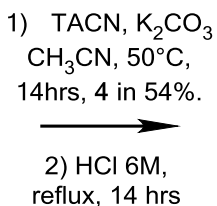

reflux, $14 \mathrm{hrs}$

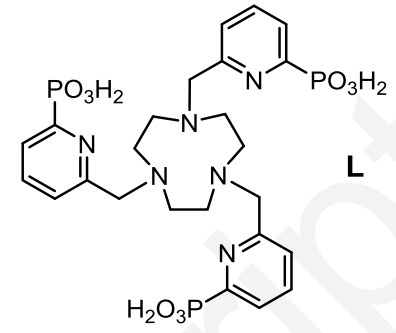

Scheme 2. Synthesis and chemical structure of ligand L

The pyridine- $N$-oxide 2 was first obtained according to literature procedure. ${ }^{26}$ diethyl (6(chloromethyl)pyridin-2-yl)phosphonate $\mathbf{3}$ was obtained by an adaptation of the procedure described for the parent pyridine, ${ }^{36}$ using ethyl chloroformate and triethylphosphite in $\mathrm{CH}_{2} \mathrm{Cl}_{2}$. Alkylation of 1,4,7-triaza-cyclonane (TACN) in acetonitrile affords precursor 4, which is hydrolyzed with $6 \mathrm{M}$ hydrochloric acid to give ligand $\mathrm{L}$ as a hydrated trihydrochloride salt.

\section{Studies of the coordination properties of ligand $L$ with $\mathrm{Ln}^{3+}$ ions $(\mathrm{Ln}=\mathrm{La}, \mathrm{Eu}, \mathrm{Tb}, \mathrm{Yb}, \mathrm{Lu})$.}

UV-visible absorption and spectrofluorimetry. The coordination properties of L with Ln cations in water at $\mathrm{pH}=7.0(0.01 \mathrm{M} \mathrm{Tris} / \mathrm{HCl})$ was investigated by monitoring the changes in UV-visible absorption and steady-state emission spectra upon addition of increasing amount of metal. Considering that the various Ln complexes formed during the experiments can be present under a very large variety of protonation states, but that we have not been able to unambiguously ascertain these later (for example by potentiometry experiments for which precipitation was observed), the protonation states of the complexes will not be specified, unless it is clearly defined (see for example the X-ray crystal structure of the Eu complex below). The absorption spectra of the ligand displayed broad bands in the UV region characteristic of $\pi \rightarrow \pi^{*}$ transitions of the pyridinephosphonate moieties, with a maximum at $267 \mathrm{~nm}\left(\varepsilon_{267}=14660 \mathrm{M}^{-1} \mathrm{~cm}^{-1}\right)$. Addition of metal salts caused a hypochromic shift of the absorption spectra concomitant with a $3 \mathrm{~nm}$ bathochromic shift (see Figures S1-S3 for $\mathrm{Ln}=\mathrm{Yb}, \mathrm{Tb}$ and $\mathrm{Eu}$ ). Similar evolutions were observed along the $\mathrm{Ln}^{3+}$ series and, in all cases, the presence of an inflexion point near one equivalent of the added $\mathrm{Ln}^{3+}$, suggested the formation of a mononuclear complex together with other polynuclear species. In the case of $\mathrm{Yb}^{3+}$, excitation in the ligand at $267 \mathrm{~nm}$ led to efficient 
sensitization of NIR $\mathrm{Yb}^{3+}$-centered luminescence by antenna effect and observation of the characteristic ${ }^{2} \mathrm{~F}_{5 / 2} \rightarrow{ }^{2} \mathrm{~F}_{7 / 2}$ emission band of $\mathrm{Yb}^{37}$ The luminescence intensity gradually increases up to $c a$ one equiv. of metal added and then slowly decreases (Figure 1), which supports the formation of a mononuclear complex together with polynuclear species under these conditions.

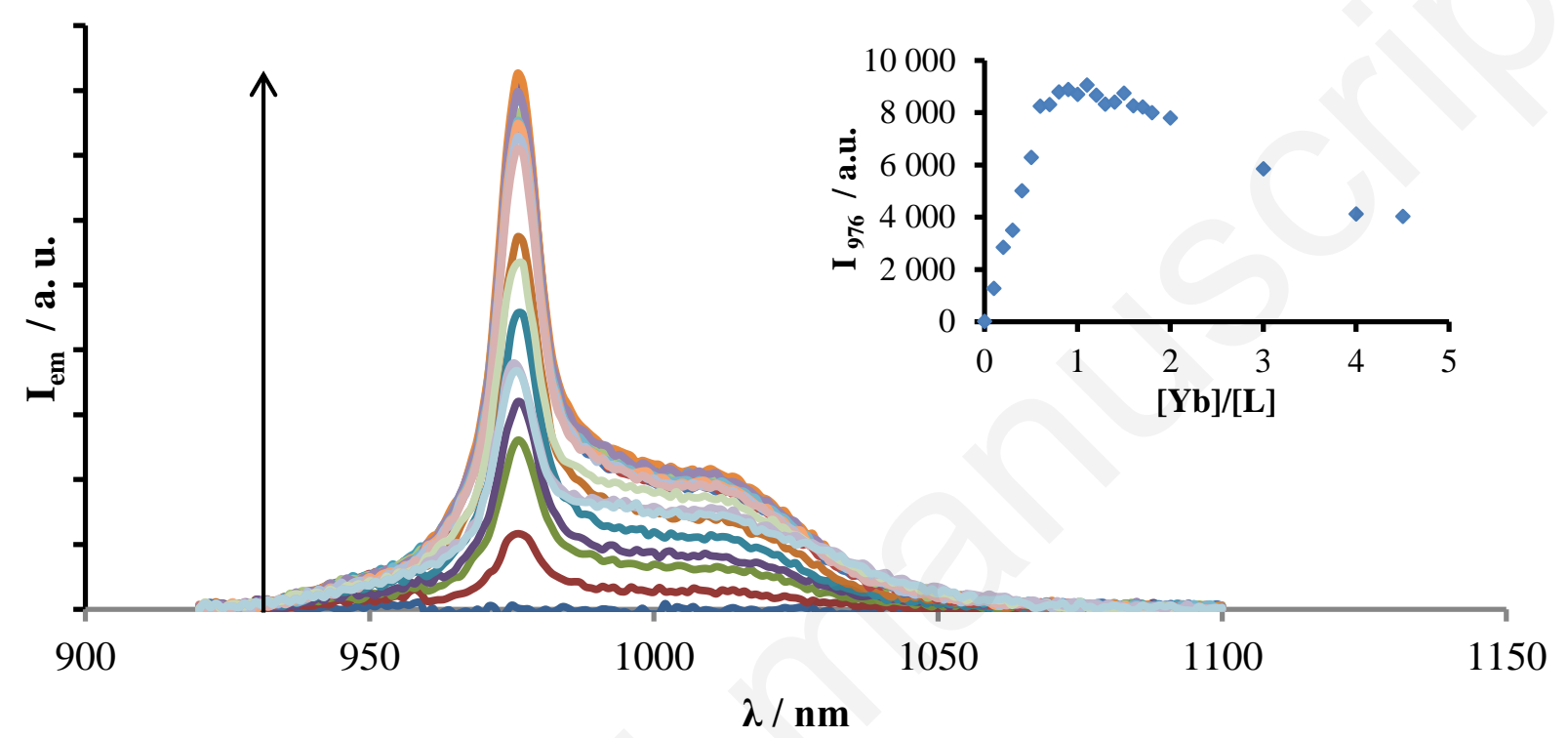

Figure 1. Evolution of the emission spectra of a solution of $\mathrm{L}$ in $0.01 \mathrm{M}$ Tris- $\mathrm{HCl}\left(4.0 \times 10^{-5} \mathrm{M}\right.$, $\left.\mathrm{pH}=7.0, \lambda_{\mathrm{ex}}=267 \mathrm{~nm}\right)$ upon addition of aliquots of $\mathrm{YbCl}_{3} \cdot 6 \mathrm{H}_{2} \mathrm{O}\left(1.14 \times 10^{-3} \mathrm{M}\right)$. Inset: evolution of the intensity at $976 \mathrm{~nm}$ as a function of the $[\mathrm{Yb}] /[\mathrm{L}]$ ratio.

These observations are also supported by measurements recorded with $\mathrm{Eu}^{3+}$ and $\mathrm{Tb}^{3+}$ cations (see Figures S4-S5) and in particular by the evolution of the average luminescence lifetimes recorded upon addition of $\mathrm{Eu}^{3+}$ and $\mathrm{Tb}^{3+}$, which significantly shorten for $[\mathrm{M}] /[\mathrm{L}]$ ratios above unity (Figure 2). 


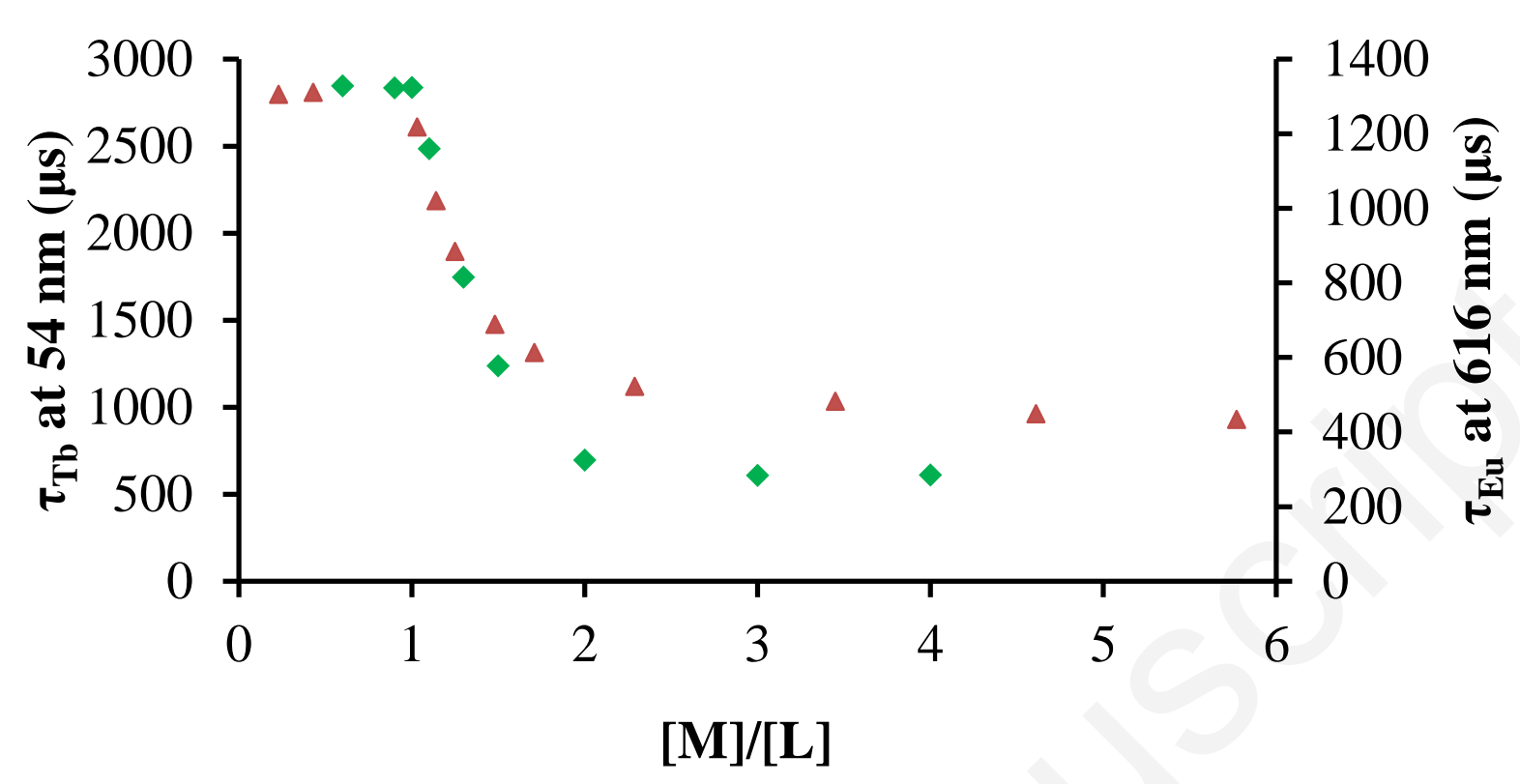

Figure 2. Evolution of the average luminescence lifetimes $\left(\lambda_{\mathrm{ex}}=267 \mathrm{~nm}\right)$ measured for the titrations of a ligand solution by $\mathrm{EuCl}_{3} \cdot 6 \mathrm{H}_{2} \mathrm{O}\left(\Delta, \lambda_{\mathrm{em}}=616 \mathrm{~nm}\right)$ and $\mathrm{TbCl}_{3} \cdot 6 \mathrm{H}_{2} \mathrm{O}\left(\diamond, \lambda_{\mathrm{em}}=545\right.$ $\mathrm{nm}$ ) (in water, TRIS/HCl $0.01 \mathrm{M}, \mathrm{pH}=7.0,[\mathrm{~L}]=5.32 \times 10^{-5} \mathrm{M}$ for Eu and $4.76 \times 10^{-5} \mathrm{M}$ for $\mathrm{Tb}$ ).

${ }^{1} \mathbf{H}$ and ${ }^{31} \mathbf{P}$ NMR studies. In order to elucidate the structure of the formed species, NMR titrations of ligand $\mathrm{L}$ with $\mathrm{Ln}=\mathrm{La}^{3+}, \mathrm{Eu}^{3+}, \mathrm{Yb}^{3+}$ and $\mathrm{Lu}^{3+}$ in $\mathrm{D}_{2} \mathrm{O}\left(\mathrm{pD}=7,25^{\circ} \mathrm{C}\right)$ were performed. The ${ }^{1} \mathrm{H}$ NMR spectra of the ligand was recorded in presence of 0 to 2.7 equiv. of $\mathrm{LuCl}_{3}$ and they are shown in Figure 3 (see Figure $\mathrm{S} 6$ for the full spectra). Between 0.2 and 0.9 equiv. of $\mathrm{Lu}^{3+}$, two sets of signals are clearly observed, which correspond to the free ligand and to the mononuclear [LuL] complex, respectively. After addition of 1 equiv. of $\mathrm{Lu}^{3+}$, complete disappearing of the ligand peaks occurred, leaving a single set of 8 signals in which 3 multiplets in the 7.4-8.0 ppm region account for the aromatic protons, one signal is observed at $3.84 \mathrm{ppm}$ for one of the two diastereotopic $\mathrm{CH}_{2}$ protons of the pendant arm, and four spin systems in the 2.22-3.38 ppm region are assigned to the protons of the tacn skeleton. This pattern is in very good agreement with a rigid mononuclear complex with $C_{3}$ symmetry. Evidence of the second methylene proton atom at $4.76 \mathrm{ppm}$, hidden by the peak of residual non-deuterated water, can be found by recording a ${ }^{1} \mathrm{H}-{ }^{1} \mathrm{H}$ COSY experiment (Figure S7). Between 1.2 equiv. and 1.8 equiv. of added $\mathrm{Lu}^{3+}$ in the solution, the peaks assigned to [LuL] disappeared and four sets of nine new 
protons were observed. Above 1.8 equiv., a broadening of the signals was observed, which was concomitant to the formation of a precipitate.
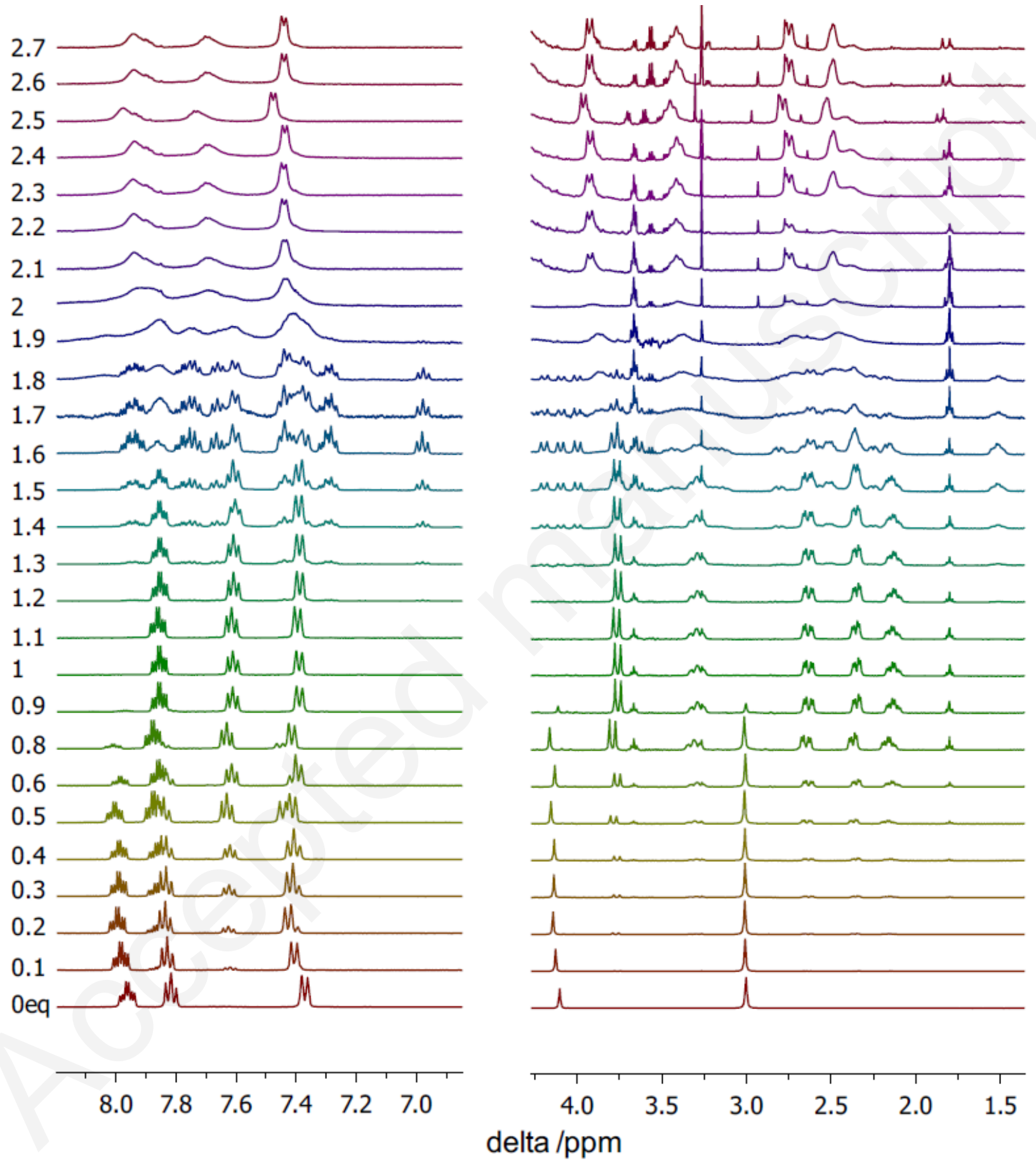

Figure 3. ${ }^{1} \mathrm{H}$ NMR spectra of ligand $\mathrm{L}$ upon addition of 0 to 2.7 equiv. of $\mathrm{LuCl}_{3} \cdot 6 \mathrm{H}_{2} \mathrm{O}\left(\mathrm{D}_{2} \mathrm{O}, \mathrm{pD}\right.$ $=7,400 \mathrm{MHz})$. 
Further insights into the structure of the species formed were obtained by monitoring the same sample by ${ }^{31} \mathrm{P}$ (Figure 4). Upon addition of 0.1 to 0.9 equiv. of $\mathrm{LuCl}_{3}$, a strong deshielding by $c a$. $9 \mathrm{ppm}$ of the ${ }^{31} \mathrm{P}$ singlet was observed, due to the coordination of the phosphonate units. No changes occured between 0.9 and 1.2 equivalent of added $\mathrm{Lu}^{3+}$ which, in line with previous observations by ${ }^{1} \mathrm{H}$ NMR, confirmed the large predominance of the monuclear [LuL] species at these stoichiometric ratios. Between 1.2 and 1.8 equivalent of metal, the peak assigned to [LuL] progressively broadened and four new signals were observed, all having the same integral within experimental error (see Figure S8 for the integration of the spectra recorded after addition of 1.6 equiv.), therefore suggesting either a unique species with four non equivalent phosphorous atoms or alternatively an equimolar mixture of two species with two non-equivalent phosphorous atoms each, possibly two diastereoisomeric species. At 1.9 equiv. and above, precipitation was observed together with the complete disappearing of the NMR peaks.

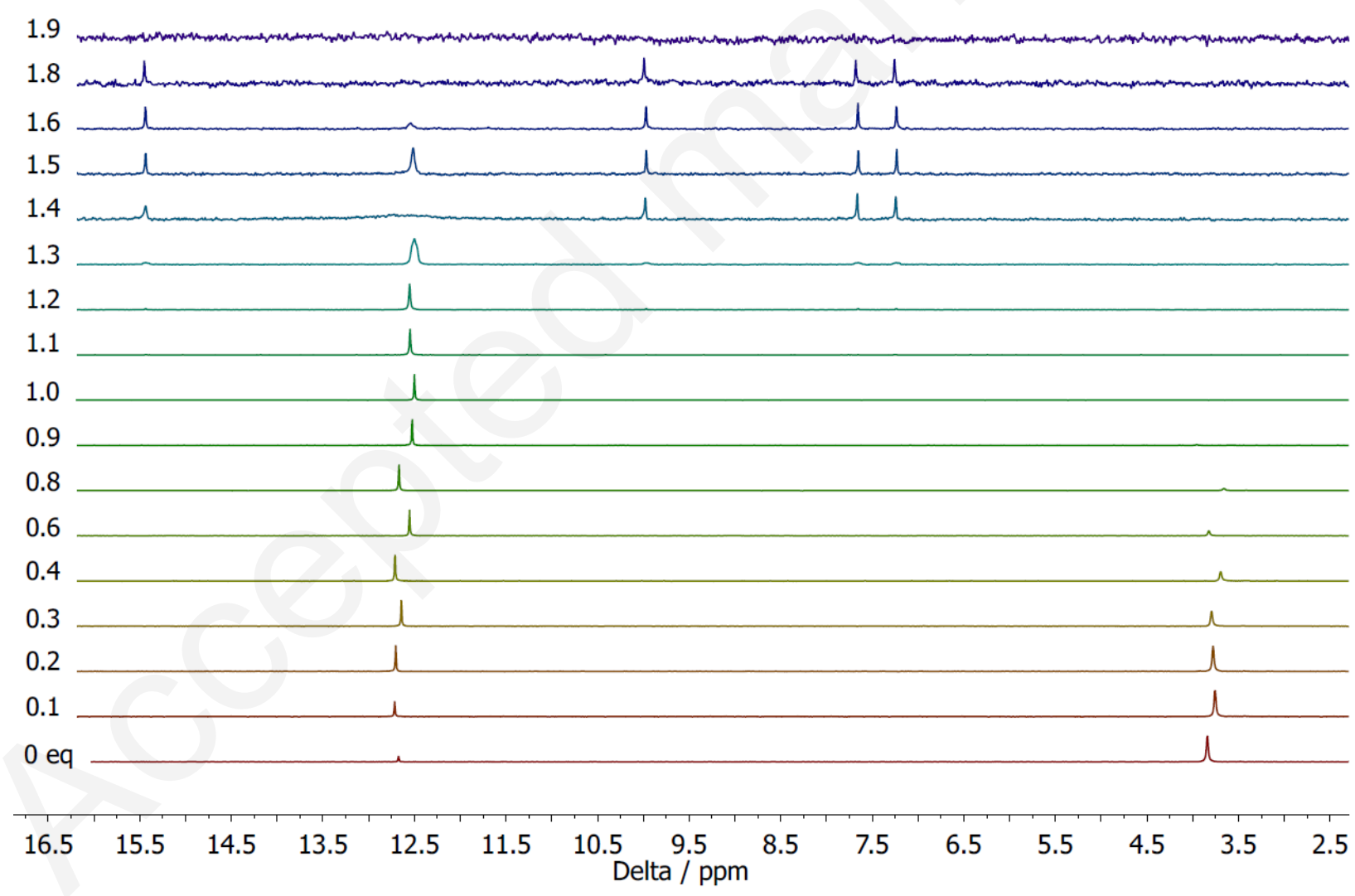

Figure 4. ${ }^{31} \mathrm{P}$ NMR spectra of ligand $\mathrm{L}$ upon addition of 0 to 1.9 equiv. of $\mathrm{LuCl}_{3} \cdot 6 \mathrm{H}_{2} \mathrm{O}\left(\mathrm{D}_{2} \mathrm{O}, \mathrm{pD}\right.$ $=7.0,162 \mathrm{MHz})$. 
Further details on the intermediate species were obtained by recording the ${ }^{1} \mathrm{H}$ and ${ }^{31} \mathrm{P}$ DOSY (Diffusion Ordered Spectroscopy) spectra in presence of 0.5, 1.2, 1.6 and 2.0 equiv. of $\mathrm{LuCl}_{3}$, respectively. The corresponding figures are displayed in the Supporting Information Section. For each species, the diffusion coefficient was determined by using ${ }^{t} \mathrm{BuOH}$ as an internal reference. In the presence of 0.5 equiv. of metal salt, two species were clearly identified and the diffusion coefficients amount to $283 \mu \mathrm{m}^{2} \mathrm{~s}^{-1}$ and $301 \mu \mathrm{m}^{2} \mathrm{~s}^{-1}$ for $\mathrm{L}$ and [LuL], respectively (Figure S9). Species with fast diffusion coefficients were also observed at $732 \mu \mathrm{m}^{2} \mathrm{~s}^{-1}$ and $1870 \mu \mathrm{m}^{2} \mathrm{~s}^{-1}$, with a chemical shift corresponding to water protons. The faster species is in good agreement with the diffusion coefficient reported for $\mathrm{HOD}$ in $\mathrm{D}_{2} \mathrm{O}\left(1902 \mu \mathrm{m}^{2} \mathrm{~s}^{-1}\right)^{38}$ and the other peak may correspond to water molecules in interaction with the second coordination sphere of the complex. As expected from ${ }^{1} \mathrm{H}$ NMR spectra, ${ }^{1} \mathrm{H}$ DOSY data in the presence of 1.2 and 1.6 equiv. were rather complex, however neat information can be obtained from ${ }^{31} \mathrm{P}$ NMR DOSY (Figure 5). In these conditions, three species could clearly be observed. The first species (with a singlet at $12.64 \mathrm{ppm}$ ) had a diffusion coefficient of $205 \mu \mathrm{m}^{2} \mathrm{~s}^{-1}$, which is in good agreement with the value determined for $[\mathrm{LuL}]$ by ${ }^{1} \mathrm{H}$ DOSY. The two other species display very close diffusion coefficients at 145 and $150 \mu \mathrm{m}^{2} \mathrm{~s}^{-1}$, respectively, which was indicative of the formation of adducts with larger sizes, each adduct giving give rise to a pair of singlets in ${ }^{31} \mathrm{P}$ NMR. Hence, they were expected to have similar size and composition. One is characterized by two singlets at $10.00 \mathrm{ppm}$ and $7.26 \mathrm{ppm}$, respectively and $\mathrm{D}=150 \mu \mathrm{m}^{2} \mathrm{~s}^{-1}$. The other gave rise to two singlets at $15.45 \mathrm{ppm}$ and $7.68 \mathrm{pm}$ and a diffusion coefficient $\mathrm{D}=145 \mu \mathrm{m}^{2} \mathrm{~s}^{-1}$ (Figure 5). The hydrodynamic radii and volumes of the three species could be obtained from the StockesEinstein equation and are summarized in Table 1. From these data, the hydrodynamic volumes calculated for the larger species were 2.5 and 2.8 times larger than the volume determined for the [LuL] monomer. On the basis of the stoichiometric proportions of the compounds in solution $\left(\left[\mathrm{Lu}^{3+}\right] /[\mathrm{L}]=1.5\right)$ and their hydrodynamic volumes, we postulated that the two sets of ${ }^{31} \mathrm{P}$ signals could be attributed to two species with a $\left[\mathrm{Lu}_{3} \mathrm{~L}_{2}\right]$ composition in agreement with the possibility of two diastereoisomers. 


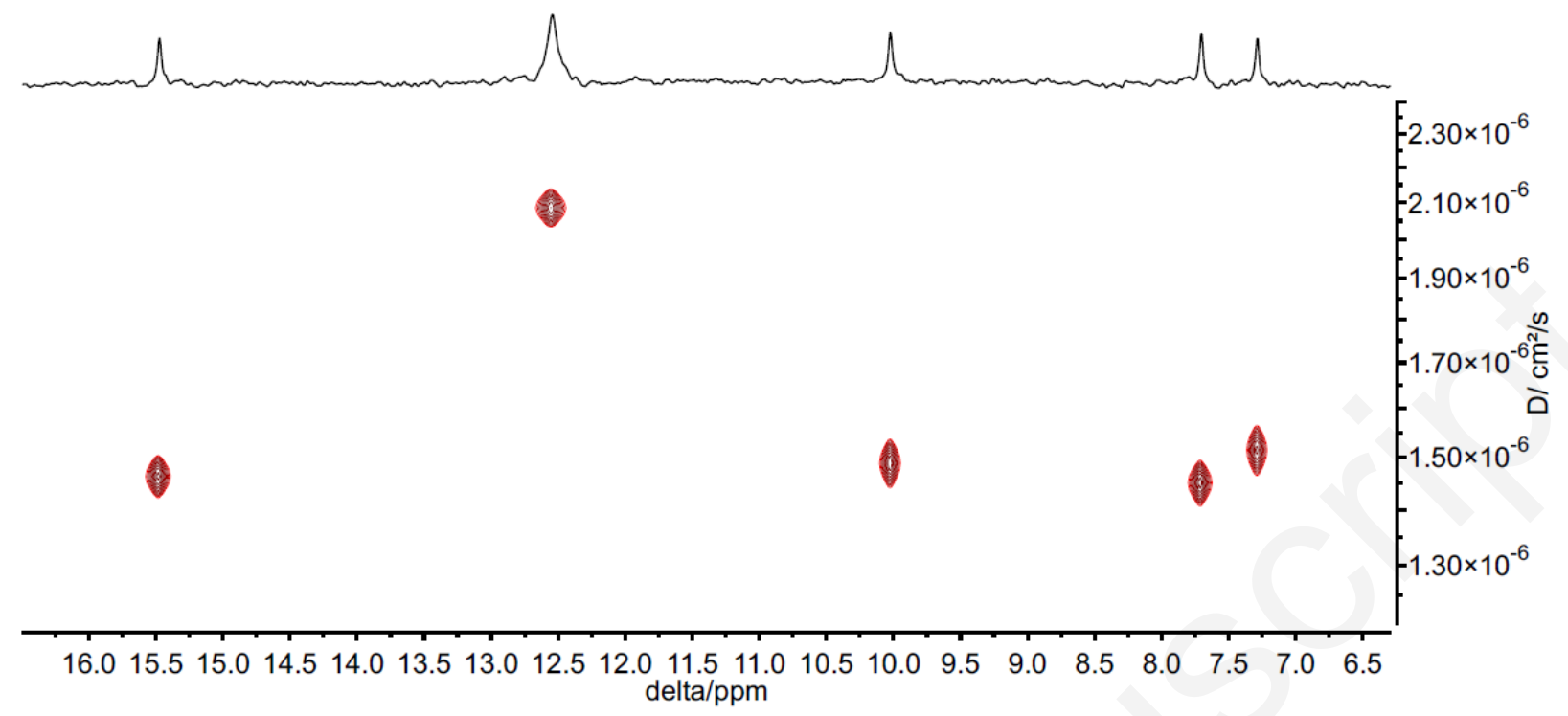

Figure 5. ${ }^{31} \mathrm{P}$ DOSY of a solution of $\mathrm{L}$ in the presence of 1.6 equiv. of $\mathrm{LuCl}_{3}$ in $\mathrm{D}_{2} \mathrm{O}\left(25^{\circ} \mathrm{C}, \mathrm{pD}=\right.$ 7).

\begin{tabular}{|c|c|c|c|c|}
\hline$\delta^{31} \mathrm{P}(\mathrm{ppm})$ & $\mathrm{D}\left(\mu \mathrm{m}^{2} / \mathrm{s}\right)$ & $\mathrm{R}_{\mathrm{H}}(\AA)$ & $\mathrm{V}_{\mathrm{H}}\left(\AA^{3}\right)$ & Species $(\mathrm{M}: \mathrm{L})$ \\
\hline 3.75 & 301 & 5.80 & 817 & $0: 1$ \\
\hline 12.54 & 205 & 8.51 & 2582 & $1: 1$ \\
\hline $7.29 / 10.2$ & 150 & 11.6 & 6538 & $3: 2$ \\
\hline $7.69 / 15.48$ & 145 & 12.0 & 7328 & $3: 2$ \\
\hline
\end{tabular}

Table 1. Diffusion coefficients (D), hydrodynamic radii $\left(\mathrm{R}_{\mathrm{H}}\right)$, hydrodynamic volumes $\left(\mathrm{V}_{\mathrm{H}}\right)$, the corresponding chemical shifts $(\delta)$ and the postulated composition of the species as obtained from ${ }^{31} \mathrm{P}$ NMR DOSY for a solution of $\mathrm{L}$ in the presence of 1.6 equiv. of $\mathrm{LuCl}_{3}$ in $\mathrm{D}_{2} \mathrm{O}\left(25^{\circ} \mathrm{C}, \mathrm{pD}=\right.$ 7).

At 2.0 equiv., broadening of the signal occured and the determination of the diffusion coefficients was no more possible, presumably because of the formation of aggregates of higher M:L stoichiometry.

Variable temperature NMR experiment were also performed on a sample with $[\mathrm{M}] /[\mathrm{L}]=1.6 .{ }^{1} \mathrm{H}$ and ${ }^{31} \mathrm{P}$ spectra from $25^{\circ} \mathrm{C}$ to $80^{\circ} \mathrm{C}$ are displayed in Figure $\mathrm{S} 10$ and S11, respectively. Significant sharpening of the ${ }^{1} \mathrm{H}$ NMR signals was clearly observed upon increasing the temperature, 
thereby suggesting the occurrence of dynamic phenomena such as chemical exchange and /or rearrangement leading to the progressive loss of the four ${ }^{31} \mathrm{P}$ signals.

${ }^{1} \mathrm{H}$ and ${ }^{31} \mathrm{P}$ NMR titrations were also performed with $\mathrm{LaCl}_{3}, \mathrm{YbCl}_{3}$ and $\mathrm{EuCl}_{3}$ and the corresponding spectra are displayed in Figures S12-S17. In all cases, the formation of a mononuclear $[\mathrm{LnL}]$ complex with rigid $C_{3}$ symmetry was clearly observed and reached its maximum concentration upon addition of 1 equiv. of metal salt. However, different behaviors were observed in excess of lanthanide ion. Addition of 1.2 equiv. of $\mathrm{YbCl}_{3}$, resulted in the formation of a non-symmetrical $\left[\operatorname{Ln}_{3} \mathrm{~L}_{2}\right]$ secondary species which became predominant at 1.6 equiv. of added metal and which was characterized by two sets of 9 peaks in the ${ }^{1} \mathrm{H}$ NMR spectrum (Figure S12). At 2.0 equiv., a third species started to grow and above, broadening of the signals was observed concomitantly to the formation of a precipitate in the tube. In the case of $\mathrm{Eu}^{3+}$ and $\mathrm{La}^{3+}$, precipitation started to occur as soon as 1.5 equiv. of metal salts were added, also suggesting the formation of new species with lower solubility.

Mass spectrometry analysis. In order to enlighten the composition of the polynuclear species, a similar titration of the ligand with 0 to 5 equiv. of $\mathrm{EuCl}_{3}$ in water (ammonium acetate $0.01 \mathrm{M}, \mathrm{pH}=7.0$ ) was monitored by ESI-mass spectrometry. Mass spectra (in positive mode) are presented in the Supporting Information. From 0 to 1 equiv. (Figure S18), the ligand peaks at $643.16 \mathrm{~m} / \mathrm{z}\left([\mathrm{M}+\mathrm{H}]^{+}\right), 665.15 \mathrm{~m} / \mathrm{z}\left([\mathrm{M}+\mathrm{Na}]^{+}\right)$and $681.11 \mathrm{~m} / \mathrm{z}\left([\mathrm{M}+\mathrm{K}]^{+}\right)$decreased to form a pattern with an isotopic peak at $791.07 \mathrm{~m} / \mathrm{z}$, which corresponds to the $[\mathrm{EuL}-2 \mathrm{H}]^{+}$species with the corresponding isotopic distribution related to ${ }^{151} \mathrm{Eu}(48 \%)$ and ${ }^{153} \mathrm{Eu}(52 \%)$. Above 1 equiv. and in the same instrumental conditions, the mononuclear complex remains the major species (Figure S19), possibly as a result of the fragmentation of the polynuclear adducts in the source, which renders the titration little informative. However, a detailed examination of the spectra recorded in the presence of 1.2 equiv. and above, indicated the presence of a series of peaks which could be attributed to polymetallic species (Figure 6). 


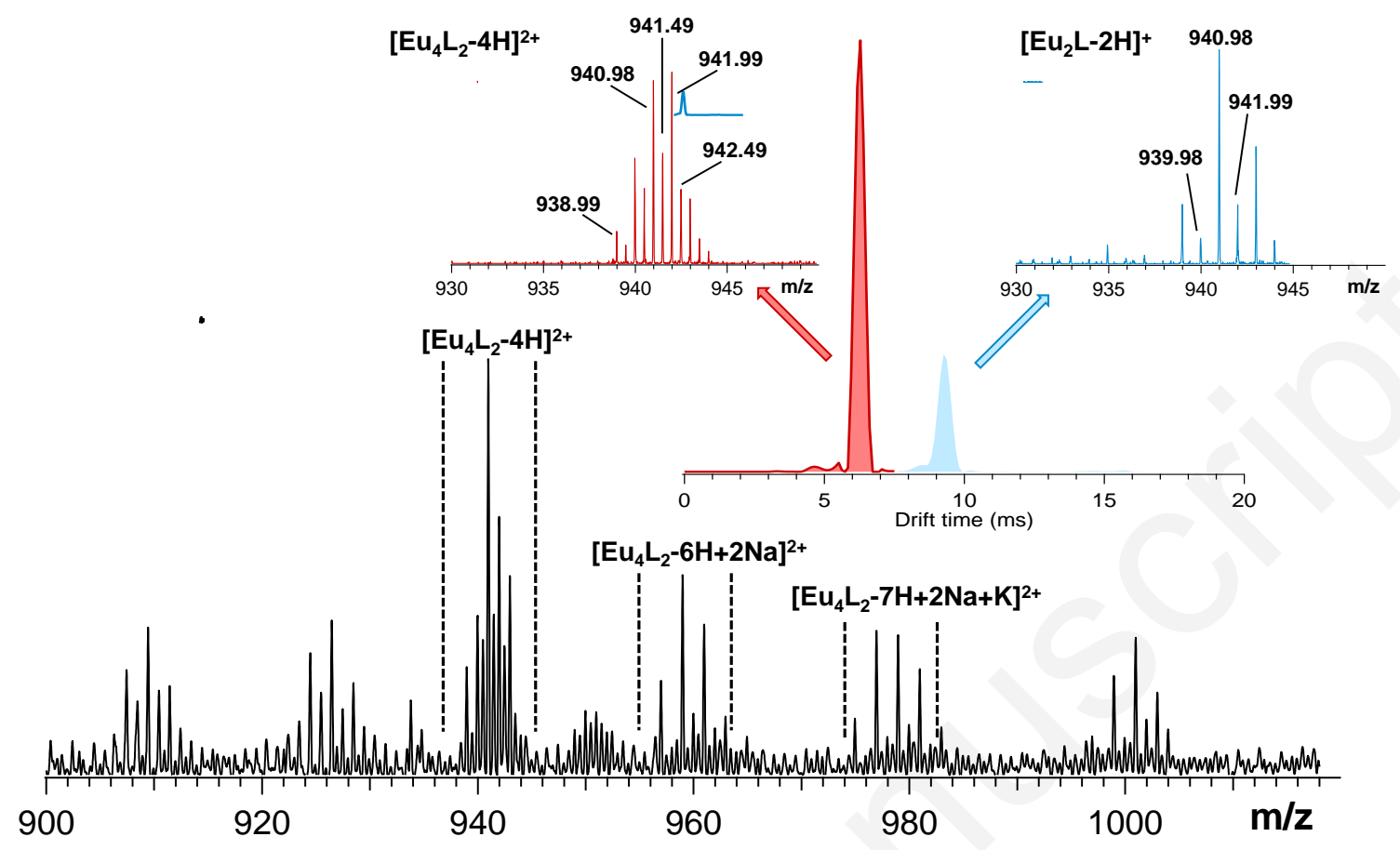

Figure 6. ESI-MS spectrum of a solution of $\mathrm{L}$ in water with 5 equiv. of $\mathrm{EuCl}_{3} \cdot 6 \mathrm{H}_{2} \mathrm{O}\left(\mathrm{AcONH}_{4}\right.$ $0.01 \mathrm{M}, \mathrm{pH}=7$ ). Inset. Arrival time distributions obtained by ion mobility for the peak at 938.99 $m / z$ and the corresponding isotopic patterns of each peak.

Ion mobility mass spectrometry experiments on the same sample were used to separate the ions at $940.97,958.98$ and $978.95 \mathrm{~m} / \mathrm{z}$ as a function of their size. Ion mobility arrival time distributions are presented on Figure 6 (inset) and on Figure S20-S21. For each peak, two contributions could be clearly evidenced, which correspond to $\left[\mathrm{Eu}_{4} \mathrm{~L}_{2}\right]^{2+}\left(\left[\mathrm{Eu}_{4} \mathrm{~L}_{2}-4 \mathrm{H}\right]^{2+}\right.$ at 938.99 $m / z,\left[\mathrm{Eu}_{4} \mathrm{~L}_{2}-6 \mathrm{H}+2 \mathrm{Na}\right]^{2+}$ at $957.00 \mathrm{~m} / z,\left[\mathrm{Eu}_{4} \mathrm{~L}_{2}-7 \mathrm{H}+2 \mathrm{Na}+\mathrm{K}\right]^{2+}$ at $\left.976.97 \mathrm{~m} / z\right)$ and $\left[\mathrm{Eu}_{2} \mathrm{~L}\right]^{+}\left(\left[\mathrm{Eu}_{2} \mathrm{~L}-\right.\right.$ $2 \mathrm{H}]^{+}$at $938.99 \mathrm{~m} / \mathrm{z},\left[\mathrm{Eu}_{2} \mathrm{~L}-2 \mathrm{H}+\mathrm{H}_{2} \mathrm{O}\right]^{+}$at $957.00 \mathrm{~m} / z,\left[\mathrm{Eu}_{2} \mathrm{~L}-3 \mathrm{H}+\mathrm{Na}+\mathrm{H}_{2} \mathrm{O}\right]^{+}$at $976.97 \mathrm{~m} / \mathrm{z}$ ) adducts. However, at this stage it was difficult to conclude whether both species were simultaneously present in solution or if aggregation of the $\left[\mathrm{Eu}_{2} \mathrm{~L}\right]^{+}$species / or dissociation of the $\left[\mathrm{Eu}_{4} \mathrm{~L}_{2}\right]^{2+}$ species occurred in the source.

Speciation and thermodynamic stability constants. In light of these observations, a global analysis of the spectrofluorimetric titration experiments was performed with the Hypspec program by implementing a model with three species with $\mathrm{M}: \mathrm{L}$ stoichiometric ratios of 1:1, 3:2 and 4:2. In both cases, such model can nicely reproduce the evolution of the emitted 
luminescence intensity as a function of the $\mathrm{M} / \mathrm{L}$ ratios (see Figures S22-S24). The overall stability constants determined for $\mathrm{Eu}^{3+}$ and $\mathrm{Tb}^{3+}$ complexes are summarized in Table 2. The calculated emission spectra of the $\mathrm{ML}, \mathrm{M}_{3} \mathrm{~L}_{2}$ and $\mathrm{M}_{4} \mathrm{~L}_{2}$ species $(\mathrm{M}=\mathrm{Eu}, \mathrm{Tb})$, together with the evolution of the concentrations of the species formed are displayed in Figures S23-S25.

\begin{tabular}{|c|c|c|}
\hline Species $\left(\mathbf{M}_{\mathbf{x}} \mathbf{L}_{\mathbf{y}}\right)$ & $\log \boldsymbol{\beta}_{\boldsymbol{E} u}$ & $\log \boldsymbol{\beta}_{\boldsymbol{T b}}$ \\
\hline $1: 1$ & 12.9 & 12.9 \\
\hline $3: 2$ & 38.6 & 36.6 \\
\hline $4: 2$ & 46 & 42 \\
\hline
\end{tabular}

Table 2. Overall stability constants of $\mathrm{Eu}^{3+}$ and $\mathrm{Tb}^{3+}$ complexes with ligand $\mathrm{L}\left([\mathrm{L}] \approx 5 \times 10^{-5} \mathrm{M}\right.$, TRIS/ $\mathrm{HCl} 0.01 \mathrm{M}, \mathrm{pH}=7.0), \lambda_{\mathrm{ex}}=267 \mathrm{~nm}$.

Assuming a minor variation of the thermodynamic stability constant along the lanthanide series, this model was used to analyze NMR data recorded with $\mathrm{Lu}^{3+}$. In particular, Figure 7 represents a comparison between the theoretical distribution species (full lines) and the intensity of the experimental ${ }^{31} \mathrm{P}$ NMR signals (points) and shows a striking correlation between ${ }^{31} \mathrm{P}$ NMR data and the previous model obtained from spectrofluorimetric titrations.

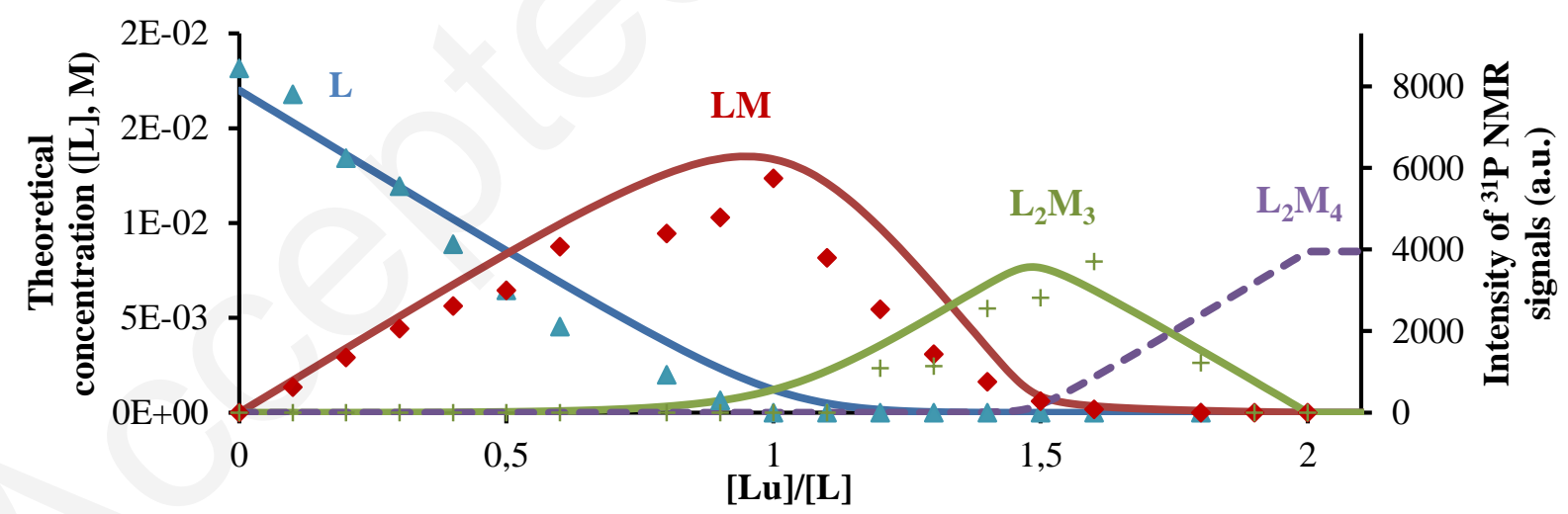

Figure 7. Theoretical representation of the concentration of the species formed (with $\log \beta_{1: 1}=12.9, \log \beta_{3: 2}=38.6, \log \beta_{4: 2}=46$, full lines) and evolution of the intensity measured by ${ }^{31} \mathrm{P}$ NMR for the three species: $\mathrm{L}(\Delta), \mathrm{LM}(\diamond), \mathrm{L}_{2} \mathrm{M}_{3}(+)$ upon titration of ligand $\mathrm{L}$ with $\mathrm{LuCl}_{3} .6 \mathrm{H}_{2} \mathrm{O}\left(\mathrm{D}_{2} \mathrm{O}, \mathrm{pD}=7.0,162 \mathrm{MHz}\right)$. Although not observed by $\mathrm{Th}_{4} \mathrm{M}_{4} \mathrm{~L}_{2}$ species was not observed by but was observed by ESI-MS and spectrofluorimetric titrations 
This analysis also endorses our initial attribution of the two sets of two peaks observed in the ${ }^{31} \mathrm{P}$ NMR spectra between 1.3 and 1.8 equiv. of Lu added, to two diastereoisomers with a 3:2 M:L stoichiometry and $C_{3}$ symmetry. In conclusion, although the identification of the polynuclear species was not straightforward, a global analysis by NMR, mass spectrometry and spectrofluorimetric experiments converged towards the evidence of the formation [ $\operatorname{Ln}_{3} \mathrm{~L}_{2}$, $\left[\mathrm{Ln}_{4} \mathrm{~L}_{2}\right]$ polynuclear species.

\section{Synthesis and spectroscopic characterization of the $[\mathrm{LnL}]$ complexes.}

Considering the high stability of the $[\mathrm{LnL}]$ complexes, it was envisaged to isolate the mononuclear complexes of $\mathrm{Eu}^{3+}, \mathrm{Tb}^{3+}, \mathrm{Yb}^{3+}$ and $\mathrm{Lu}^{3+}$. In order to determine the optimal conditions for their synthesis and purification, the influence of the $\mathrm{pH}$ on a solution containing stoichiometric amounts of $\mathrm{L}$ and $\mathrm{EuCl}_{3} \cdot 6 \mathrm{H}_{2} \mathrm{O}$ was first monitored by recording the $\mathrm{Eu}^{3+}$ emission spectra upon excitation in the ligand absorption band (Figure S26). This titration indicated that complete formation of the complex occured above $\mathrm{pH}=4.45$ and once formed, the [EuL] complex remained stable in the $\mathrm{pH}$ range from 12.04 to 1.98 . Hence, the formation of the desired mononuclear complexes was achieved at neutral $\mathrm{pH}$ whereas their precipitation and purification was accomplished in slightly acidic conditions $(\mathrm{pH}=3.5)$, in order to avoid the formation of polynuclear complexes. The complexes were further purified by reverse phase chromatography on C18 and analyzed by elemental analysis and ESI mass spectrometry, showing expected isotopic patterns for $[\mathrm{LnL}-2 \mathrm{H}]^{+}$species (Figures S7-S29). The complexes were further characterized by ${ }^{1} \mathrm{H}$ and ${ }^{31} \mathrm{P}$ NMR spectroscopy, except for $\mathrm{Tb}^{3+}$, each one giving a set of 9 signals in ${ }^{1} \mathrm{H}$ NMR (Figures S30-S32) and a singlet at $12.51 \mathrm{ppm},-8.71 \mathrm{ppm}$ and $2.51 \mathrm{ppm}$, for the ${ }^{31} \mathrm{P}$ NMR spectra for $\mathrm{Lu}, \mathrm{Eu}$ and $\mathrm{Yb}$, respectively.

Finally, the spectroscopic properties of the complexes were measured in water and $\mathrm{D}_{2} \mathrm{O}$ and the corresponding absorption and emission spectra are presented in Figure 8. Additional parameters are presented in Table 3 and three points have attracted our attention. At first, strictly monoexponential luminescence decays confirm the presence of unique species in solution. Second, the absence of inner-sphere water molecule endorses the nonadentate coordination of the ligand and the good protection of the metal inside the cavity. Third, the luminescence properties of the $\mathrm{Yb}$ complex are rather interesting in terms of lifetimes and quantum yields. In particular, the lifetime 
measured in deuterated water is rather long in comparison to typical values obtained for efficient $\mathrm{Yb}^{3+}$ emitters ${ }^{39,40,41,42,43,44}$ and longer than the one previously reported for the tacn-based $\left[\mathrm{Yb}\right.$ (thqten-SO $\left.\left.\mathrm{S}_{3}\right)\right](8.63 \mu \mathrm{s}) .{ }^{14}$ However, this value remains significantly shorter than the values obtained for $\mathrm{YbL}^{2}$ and $\mathrm{YbL}^{2 \mathrm{D}}\left(>30 \mu \text { s in } \mathrm{D}_{2} \mathrm{O}\right)^{8}$ and other per-deuterated complexes in organic solvents. ${ }^{45,46,47}$

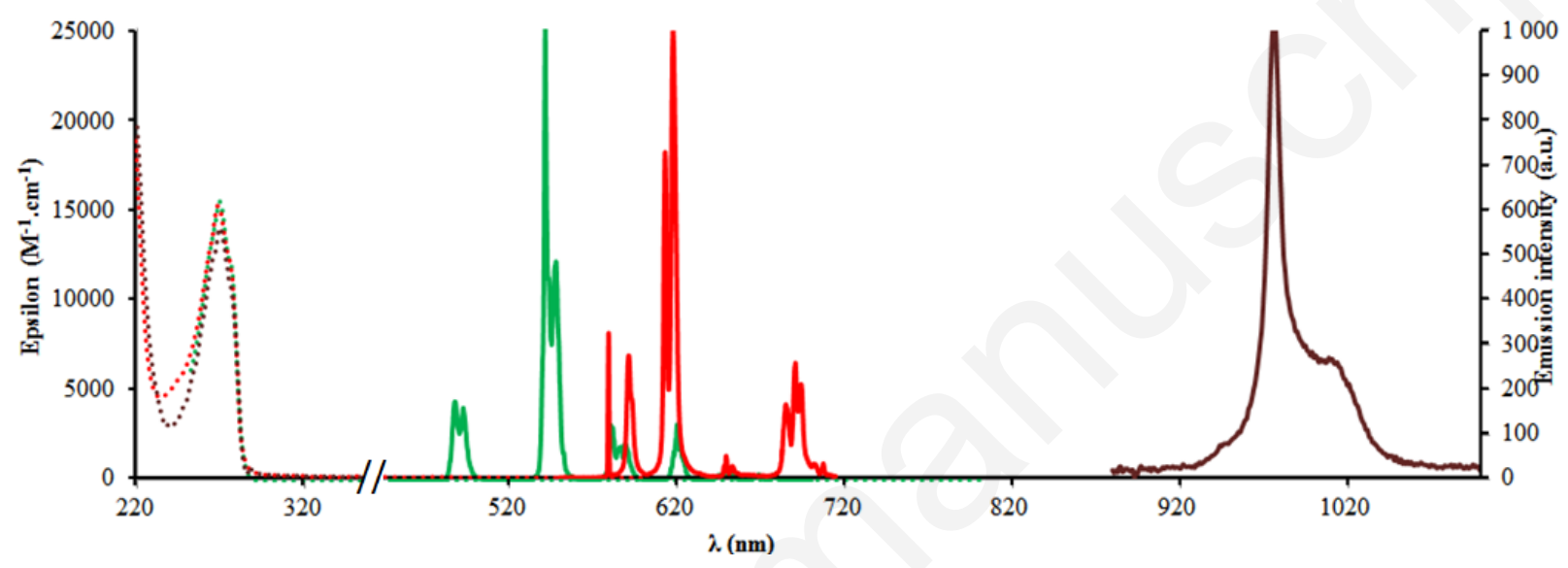

Figure 8. UV/Vis absorption (dotted lines) and normalized emission $\left(\lambda_{\mathrm{ex}}=265 \mathrm{~nm}\right.$ ) of a $\mathrm{D}_{2} \mathrm{O}$ solution of $[\mathrm{LnL}]$ (straight lines) with $\mathrm{Ln}=\mathrm{Yb}$ (brown), $\mathrm{Tb}$ (green) and $\mathrm{Eu}$ (red).

\begin{tabular}{|c|c|c|c|c|c|c|c|}
\hline & $\varepsilon_{\mathbf{H}_{\mathbf{2}} \mathbf{0}}\left(\mathrm{M}^{-1} \mathrm{~cm}^{-1}\right)^{[\mathrm{a}]}$ & $\varepsilon_{\mathbf{D}_{\mathbf{2}} \mathbf{0}}\left(\mathrm{M}^{-1} \mathrm{~cm}^{-1}\right)^{[\mathrm{a}]}$ & $\phi_{\mathbf{H}_{\mathbf{2}} \mathbf{0}}(\%)^{[\mathrm{b}]}$ & $\phi_{\mathbf{D}_{\mathbf{2}} \mathbf{0}}(\%)^{[\mathrm{b}]}$ & $\tau_{\mathbf{H}_{\mathbf{2}} \mathbf{O}}(\mu \mathrm{s})$ & $\tau_{\mathbf{D}_{\mathbf{2}} \mathbf{0}}(\mu \mathrm{s})$ & $q^{[\mathrm{c}]}$ \\
\hline $\mathrm{YbL}$ & 13050 & 13300 & 0.15 & 0.42 & 2.8 & 10.2 & 0.0 \\
\hline $\mathrm{TbL}$ & 14880 & 15450 & 51 & 52 & 2890 & 2980 & -0.2 \\
\hline $\mathrm{EuL}$ & 12260 & 13870 & 2 & 8 & 1252 & 1375 & -0.2 \\
\hline $\mathrm{LuL}$ & 12610 & - & - & - & - & - & - \\
\hline
\end{tabular}

${ }^{[a]} \lambda=265 \mathrm{~nm} .{ }^{[b]} \phi$ measured relative to $\left[\mathrm{Ru}(\text { bipy })_{3} \mathrm{Cl}_{3}\right]^{32}$ for $\mathrm{Eu},\left[\mathrm{TbL}\left(\mathrm{H}_{2} \mathrm{O}\right)\right]^{33}$ for Tb and to IR $125^{34}$ for $\mathrm{Yb} .{ }^{[\mathrm{c}]}$ Calculated according to ref 48 .

Table 3. Main spectroscopic parameters of the YbL, TbL, EuL and LuL complexes in water and $\mathrm{D}_{2} \mathrm{O}$ at $\mathrm{pH}=7.0$. 
Surprisingly, despite the excellent shielding of the cations from the solvent molecules ( $\mathrm{q} \approx 0$ for all complexes), the luminescence quantum yields of the Eu complex were rather modest compared to those obtained with ligands possessing carboxy pyridyl arms (picolinates) ${ }^{49,50}$ or phosphinate ones..$^{51}$ Considering the good shielding and the long luminescence lifetimes, it is surmised that these poor luminescence quantum yields are to be linked with a modest ligand to metal energy transfer.

\section{Structural studies of the mono- and poly-nuclear species.}

While isolating the mononuclear complexes, single crystals suitable for X-ray diffraction analysis were obtained for [EuL], which was isolated in acidic conditions as a mixture of [EuL], and $[\mathrm{EuLH}] \mathrm{Cl}$ species. The ORTEP diagram is represented in Figure 9. Selected parameters, distances and angles are presented in Tables S1-S2. The metal ion is nine-coordinated by three nitrogen atoms from the tacn ring, three nitrogen atoms from the aromatic groups and three oxygen atoms from the phosphonate functions with a pseudo- $\mathrm{C}_{3}$ symmetry. The pyridinephosphonate pendant arms bind the lanthanide in a helical fashion and both enantiomers ( $\Delta$ and $\Lambda$ ) are present in the solid state structures, therefore leading to centrosymmetric space groups $\left(P 2_{1} / a\right)$. Similar structures have previously been collected for tacn-based ligands with pyridinecarboxylate, ${ }^{13} 8$-hydroxyquinoline pendant arms,${ }^{14}$ and 6-carboxy-2,2'-bipyridine arms. ${ }^{12}$ 


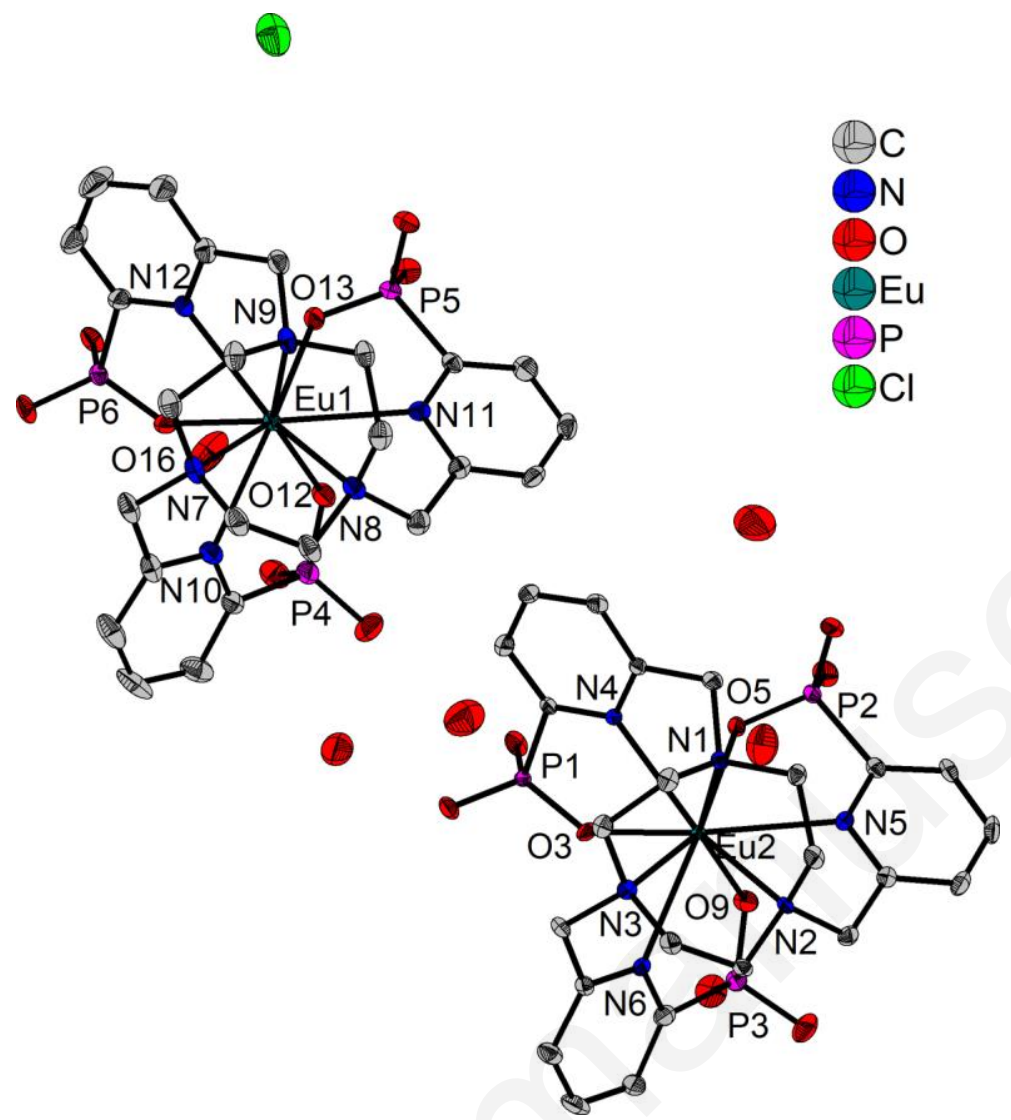

Figure 9. ORTEP diagram of the complexes [EuL], [EuLH]Cl with thermal ellipsoids at 50\% probability.

Interestingly, single crystals could be obtained upon cooling a water solution of ligand L containing 1.5 equiv. of lanthanum chloride, originally heated at $80^{\circ} \mathrm{C}$. The crystal structure of the $\left[(\mathrm{LaL}) \mathrm{La}\left(\mathrm{H}_{2} \mathrm{O}\right)_{9}\right]$ species is represented in Figure 10. Structural parameters and selected distances and angles are summarized in Tables S1 and S2. The structure is composed of a nonacoordinated $[\mathrm{LaL}]^{3-}$ mononuclear complex in which the $\mathrm{La}^{3+}$ cation is coordinated inside the cavity of the ligand as for the mononuclear [EuL] complex,, (noted Lal) together with a nonahydrated $\left[\mathrm{La}\left(\mathrm{H}_{2} \mathrm{O}\right)\right]^{3+}$ complex (noted $\mathrm{La} 2$ ). Considering the $C_{3}$ symmetry of [La1L], the position of the phosphonate allows to define two kind of interactions between La1 and La2, a head to head $(\mathrm{HH})$ one in which the phosphonate functions of [La1L] point toward La2 and Head to tail (HT) interaction in which La2 faces the triazacyclononane macrocycles. The two motives are repeated along the c axis, at distances of $5.716 \AA$ (HH) and $8.461 \AA$ (HT) between the two lanthanum ions (Figure 11). In a column, all [La1L] complex display the same chirality $(\Delta$ or $\Lambda$ ). 
This chirality is inverted between two adjacent column. Within the two entities in a $\mathrm{HH}$ conformation, the three water molecules coordinated to the hydrated La2 atom and pointing toward the $[\mathrm{La} 1 \mathrm{~L}]$ complex are held by a H-bond network in which the two proton atoms of a water molecule are linked to one oxygen atom of a phosphonate function coordinated to La1 and to an oxygen atom not directly coordinated to Lal of an adjacent phosphonate function (blue dashed lines in Figure 11).

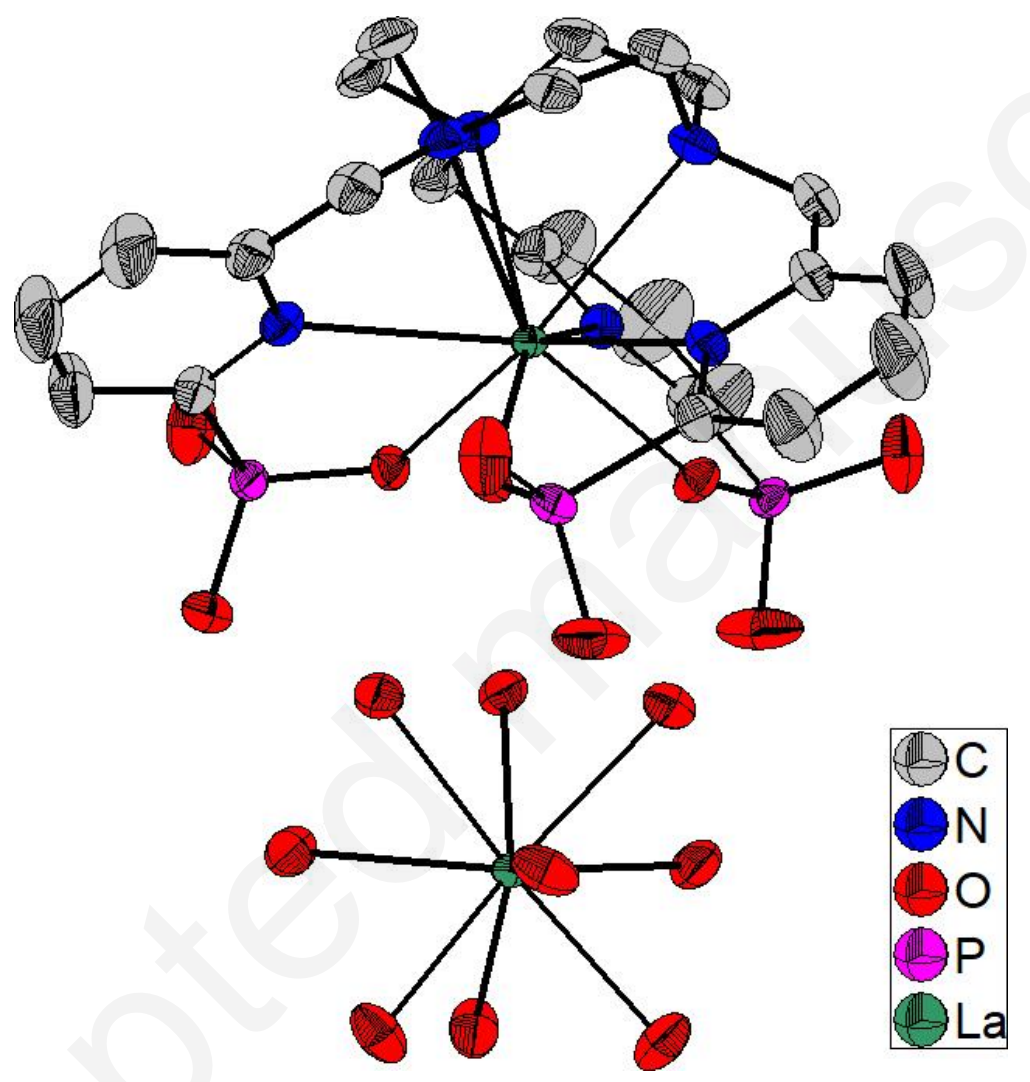

Figure 10. Solid state structure of the $\left[(\mathrm{LaL}) \mathrm{La}\left(\mathrm{H}_{2} \mathrm{O}\right)_{9}\right]$ complex (ellipsoids drawn at $50 \%$ probability).

The three water molecules coordinated in the equatorial plane of La2 (relative to the pseudo- $C_{3}$ axis) are also hydrogen bonded to the three oxygen atoms of the phosphonate functions of the neighbouring [La1L] complex (black dashed lines in Figure 11). The other $\mathrm{H}$ atom of these water molecules are bonded to an oxygen atom of a phosphonate function of a [La1L] complex from an adjacent column (isolated oxygen atoms in red in Figure 11). 
Weak interactions are also observed between $\left[\mathrm{La}\left(\mathrm{H}_{2} \mathrm{O}\right)_{9}\right]$ and a neighbouring [La1L] complex in the HT configuration. These interactions are relayed by three water molecules or by the oxygen atom of a phosphonate function of a [La1L] complex in a neighbouring column (green dashed lines in Figure 11).

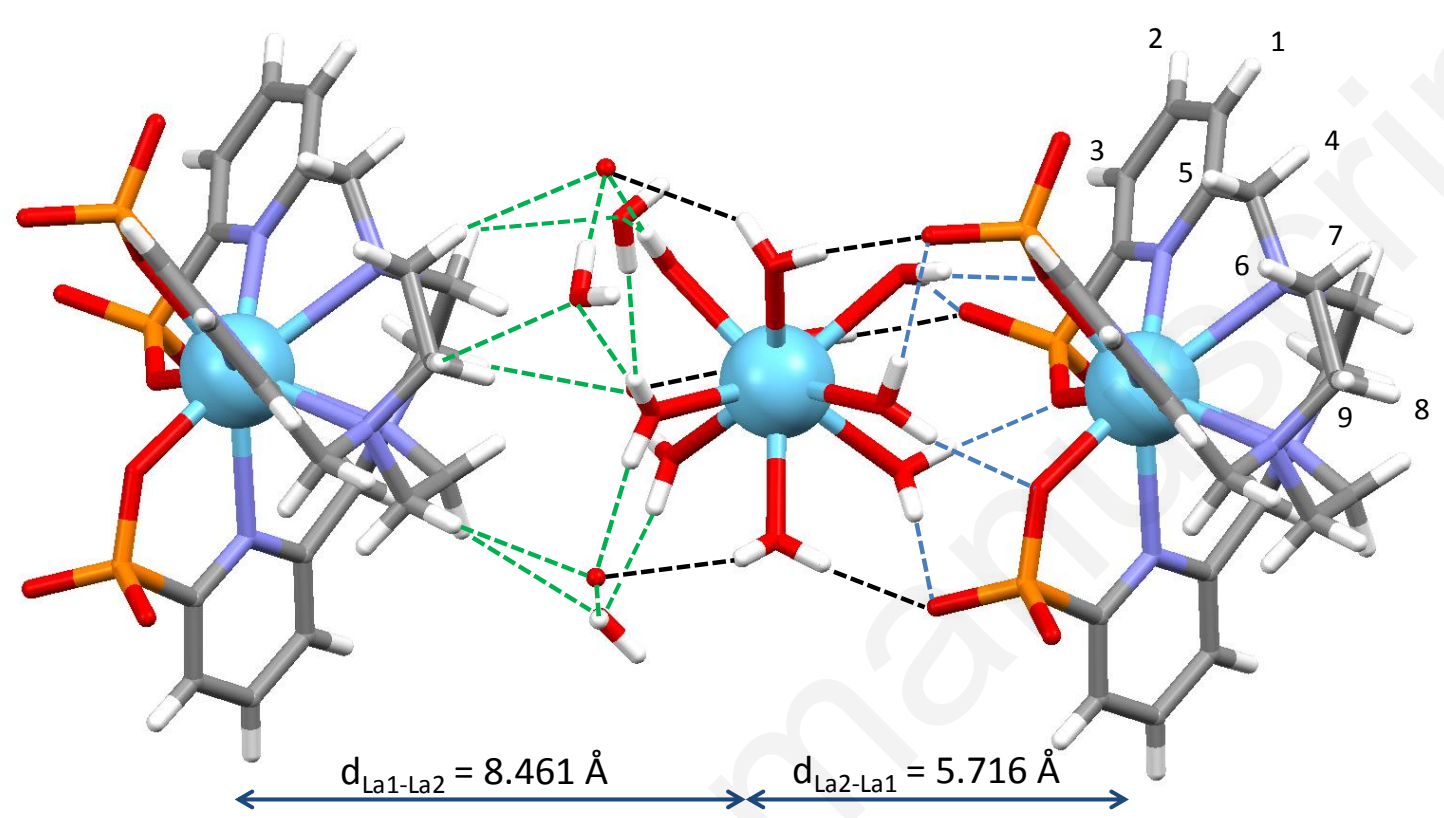

Figure 11. Representation of the hydrogen bonding interactions observed in the crystal structure of the $\left[(\mathrm{LaL}) \mathrm{La}\left(\mathrm{H}_{2} \mathrm{O}\right)_{9}\right]$ complexes (see text for the color code of $\mathrm{H}$ bonding interactions) and numbering scheme of the $\mathrm{H}$ atoms used for the interpretation of the NMR spectrum.

We hypothesized that this strong $\mathrm{H}$ bonding network may be responsible for the high stability of the $\left[\mathrm{Lu}_{3} \mathrm{~L}_{2}\right]$ species observed by NMR and spectroscopy in solution. For a trinuclear complex in the THH configuration $([(\mathrm{LuL}) \mathrm{Lu}(\mathrm{LuL})]$ as schematized in Figure 11), one would expect the observation of two peaks in the ${ }^{31} \mathrm{P}-\mathrm{NMR}$, depending on the HH or HT interaction between the central $\mathrm{Lu}$ atom and the LuL complex. If one now assumes that the chirality of the LuL complexes in the trinuclear complexes can be exchange for one of the LuL complex, two pairs of peaks would be expected for the $[\Delta(\mathrm{LuL}) \mathrm{Lu} \Delta(\mathrm{LuL})]$ and $[\Delta(\mathrm{LuL}) \mathrm{Lu} \Lambda(\mathrm{LuL})]$ diastereoisomeric species.

To further confirm this hypothesis, a mixture containing 1.4 equivalent of $\mathrm{LuCl}_{3} \cdot 6 \mathrm{H}_{2} \mathrm{O}$ per ligand L was analyzed by ${ }^{1} \mathrm{H}, \mathrm{COSY}$, NOESY and ROESY NMR experiments. The attribution of the signals is presented on Figure 12. On this spectrum, five families of 9 signals were observed and 
their attribution could be partially performed by looking at ${ }^{1} \mathrm{H}-{ }^{-1} \mathrm{H}$ correlations in the COSY experiment (Figure 12). The first family (1-9, in black) corresponds to the mononuclear [LuL] complex. Nuclear Overhauser effect was observed between $\mathrm{H} 1$ and H4/5, however dipole-dipole interactions between other species could not be observed. Their attribution was possible with the examination of the ROESY spectrum, based on the $1^{x}, 4 / 5^{x}$ correlations $(x=,,,, \circ$, Figure S33). No correlation could clearly be distinguished for the fourth family $\left(1 *_{-} 9^{*}\right.$, in blue). Another striking point in the examination of the NOESY spectrum (Figure S34) is the observation of exchange correlations between, on the one hand, the two protons 4 and 5 corresponding to the $\mathrm{AB}$ system and, on the other hand, between proton atoms from the triazacyclononane backbone such as $7^{*}$ and $7^{\prime}, 7^{\circ}$ and 7 or $8^{\prime \prime}$ and 8 . Such exchanges are typical of $\Delta \leftrightarrow \Lambda$ interconversion processes associated to the concerted rotation of the pendant arms in $C_{3}$ symmetric $\mathrm{LnL}$ complexes. However this observation is particularly surprising for two reasons. The $\Delta \leftrightarrow \Lambda$ interconversion process could not be observed in the isolated [LuL] complex, even by heating the solution up to $80^{\circ} \mathrm{C}$ in $\mathrm{D}_{2} \mathrm{O}$ and is not observed in the NOESY spectrum for the $\mathrm{AB}$ spin system of $\mathrm{H} 4$ and $\mathrm{H} 5$ protons of the remaining [LuL] complex. Then, if such an isomerization has already been observed for lanthanide complexes with 1,4,7-triazacyclononane derivatives such as $\mathrm{H}_{4}$ nota $^{52}$ and $\mathrm{H}_{3}$ bpatcn ${ }^{53}$, they always correspond to ligands with decreased denticity (CN $=6$ for $\mathrm{H}_{4}$ nota and 8 for $\mathrm{H}_{3}$ bpatcn), whereas isomerization was not reported for tacn ligands with functionalized pyridines displaying $\mathrm{CN}=9$. On the opposite, enantiopure $\mathrm{Eu}$ and $\mathrm{Tb}$ complexes with trispyridylphosphinate triazacyclononane could be isolated, either using chiral HPLC $^{17}$ or directly synthesized thanks to the inclusion of a stereogenic centre on the tcn ring. ${ }^{54}$

A possible explanation of the observed exchange is that the interconversion occurs between the diastereomeric pairs, exchanging the $[\Delta(\mathrm{LuL}) \mathrm{Lu} \Delta(\mathrm{LuL})]$ into the $[\Lambda(\mathrm{LuL}) \mathrm{Lu} \Lambda(\mathrm{LuL})]$ (and similarly with $[\Lambda(\mathrm{LuL}) \mathrm{Lu} \Delta(\mathrm{LuL})]$ and $[\Delta(\operatorname{LuL}) \operatorname{Lu} \Lambda(\mathrm{LuL})])$. Considering that the $\Delta \leftrightarrow \Lambda$ interconversion of $[\mathrm{LuL}]$ is slow on the NMR timescale, the exchange between the diastereomeric pairs would require a dissociation process. Unfortunately, within a dyad such as depicted in Figure 9, distances between the two mononuclear LuL complexes are two high to expect any correlations by 2D NOESY NMR. Interestingly, ${ }^{1} \mathrm{H}$ NMR spectra of mixed species have been recorded by addition of 1 equivalent of $\mathrm{LuCl}_{3}$ on the mononulclear [YbL] complex and by addition of 1 equivalent of $\mathrm{YbCl}_{3}$ and [LuL] (Figure S35), and indicate no decoordination 
and no ion exchange at room temperature and upon heating up to $80^{\circ} \mathrm{C}$, therefore confirming the formation of kinetically inert complexes.

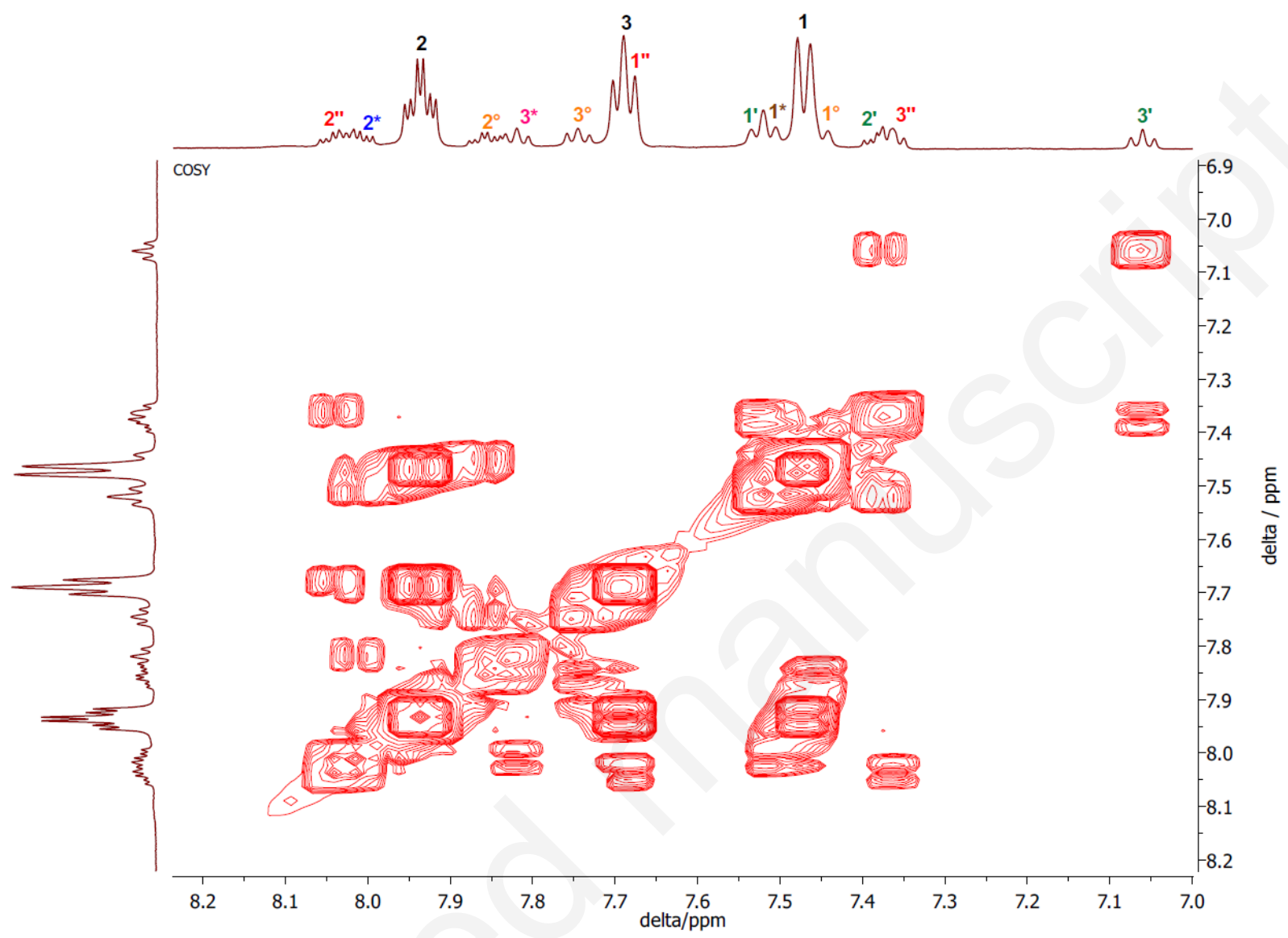




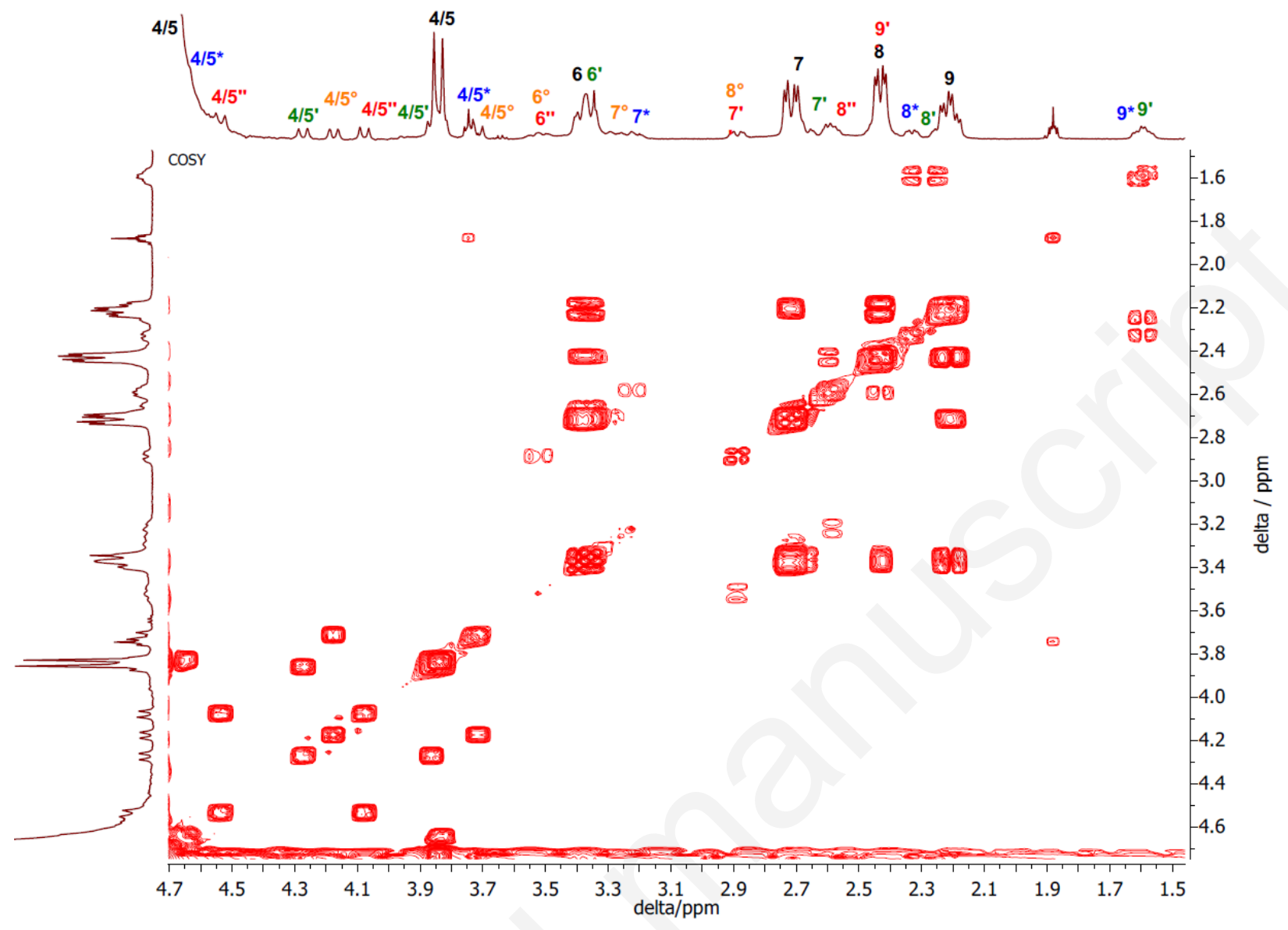

Figure 12. ${ }^{1} \mathrm{H}-{ }^{1} \mathrm{H}$ COSY spectra of ligand $\mathrm{L}$ upon addition of 1.4 equiv. of $\mathrm{LuCl}_{3} \cdot 6 \mathrm{H}_{2} \mathrm{O}\left(\mathrm{D}_{2} \mathrm{O}, \mathrm{pD}\right.$ $=7,400 \mathrm{MHz}$ ) and peak assignment (see numbering on Figure 11).

\section{Conclusion}

In conclusion, the assembly of pyridinephosphonate units into the nonadentate tripodal ligand $\mathrm{L}$ allows the synthesis of highly stable monomeric lanthanide complexes that are isostructural along the series. Moreover, such complexes are highly stable in water and display luminescent properties, due to an efficient sensitization of $\mathrm{Eu}, \mathrm{Tb}$ and $\mathrm{Yb}$ ions by the pyridinephosphonate antenna. More importantly, such scaffold is responsible for relatively low vibrational quenching, as emphasized by the very good luminescence properties of the $\mathrm{Yb}$ complex in $\mathrm{D}_{2} \mathrm{O}\left(\tau_{\mathrm{D} 2 \mathrm{O}}=10.2\right.$ $\mu \mathrm{s}$ and $\left.\phi_{\mathrm{D} 2 \mathrm{O}}=0.42 \%\right)$. Furthermore, using a combination of UV-absorption spectrometry, spectrofluorimetry, ${ }^{1} \mathrm{H}$ and ${ }^{31} \mathrm{P}$ NMR, DOSY, ESI-mass spectrometry and X-Ray diffraction, we 
demonstrated that this nonadentate ligand is a good building block for the formation of highly stable polynuclar complexes of $\left[(\operatorname{LnL})_{2} \operatorname{Ln}_{\mathrm{x}}\right]$ stoichiometry $(\mathrm{x}=1$ and $\mathrm{x}=2)$. Such architectures are very interesting for studying intermetallic communication and energy transfer within heteropolynuclear species and can potentially lead to very appealing photon up conversion properties. Future works are engaged in this direction.

\section{ASSOCIATED CONTENT}

Supporting Information. Evolution of the UV-visible absorption and emission spectra of a solution of L upon addition of $\mathrm{Yb}^{3+}, \mathrm{Tb}^{3+}$ and $\mathrm{Eu}^{3+}$ (Figures S1-S5); ${ }^{1} \mathrm{H}$ NMR, ${ }^{31} \mathrm{P}$ NMR and ${ }^{1} \mathrm{H}$ DOSY experiments with Lu:L mixtures (Figures S6-S11); ${ }^{1} \mathrm{H}$ and ${ }^{31} \mathrm{P}$ NMR titrations of ligand $\mathrm{L}$ with $\mathrm{Yb}^{3+}$ (Figures S12-S13), $\mathrm{Eu}^{3+}$ (Figures S14-S15) and $\mathrm{La}^{3+}$ (Figures S16-S17); ESI-MS titrations of $\mathrm{L}$ with $\mathrm{Eu}^{3+}$ and ionic mobility chromatograms (Figures S18-S21); calculated spectra and species distribution diagrams for the spectrofluorimetric titrations of $\mathrm{L}$ with $\mathrm{Eu}^{3+}$ (Figures $\mathrm{S} 22-\mathrm{S} 23$ ) and $\mathrm{Tb}^{3+}$ (Figures S24-S25); $\mathrm{pH}$ titration of a solution of Eu:L 1:1 (Figure S26); ESIMS and ${ }^{1} \mathrm{H}$ NMR spectra of isolated [EuL] (Figures S27-S31); [LuL] (Figures S28-S30); [YbL] (Figures S29-S32); crystallographic data for [EuL] and [LaL] structures (Tables S1-S3); 2D ${ }^{1 \mathrm{H}}$ NMR spectra of a L:Lu 1:1.4 mixture (Figures S33-S34). This material is available free of charge via the Internet at http://pubs.acs.org.

\section{AUTHOR INFORMATION}

\section{Corresponding Author}

*1.charbonn@unistra.fr; aline.nonat@unistra.fr

\section{Author Contributions}

The manuscript was written through contributions of all authors. All authors have given approval to the final version of the manuscript. $\ddagger$ These authors contributed equally.

\section{Funding Sources}

Any funds used to support the research of the manuscript should be placed here (per journal style). 


\section{Notes}

The authors declare no competing financial interest.

\section{ACKNOWLEDGMENT}

This work was supported by the French Centre National de la Recherche Scientifique and the University of Strasbourg. The authors thank Lionel Allouche (Service commun de RMN, Université de Strasbourg) for the acquisition and the interpretation of the DOSY experiments and Jean-Marc Strub for his help when recording mass spectra. The authors thank GIS IBiSA and Région Alsace for financial support in purchasing a Synapt G2 HDMS instrument.

\section{REFERENCES}

(1) Resch-Genger, U.; Gorris, H. H. Perspectives and Challenges of Photon-Upconversion Nanoparticles - Part I: Routes to Brighter Particles and Quantitative Spectroscopic Studies. Anal. Bioanal. Chem. 2017, 409 (25), 5855-5874.

(2) Auzel, F. Upconversion and Anti-Stokes Processes with f and d Ions in Solids. Chem. Rev. 2004, 104 (1), 139-174.

(3) Liu, X.; Qiu, J. Recent Advances in Energy Transfer in Bulk and Nanoscale Luminescent Materials: From Spectroscopy to Applications. Chem. Soc. Rev. 2015, 44 (23), 87148746.

(4) Haase, M.; Schäfer, H. Upconverting Nanoparticles. Angew. Chem. Int. Ed. 2011, 50 (26), 5808-5829.

(5) Suffren, Y.; Golesorkhi, B.; Zare, D.; Guénée, L.; Nozary, H.; Eliseeva, S. V.; Petoud, S.; Hauser, A.; Piguet, C. Taming Lanthanide-Centered Upconversion at the Molecular Level. Inorg. Chem. 2016, 55 (20), 9964-9972.

(6) Hyppänen, I.; Lahtinen, S.; Ääritalo, T.; Mäkelä, J.; Kankare, J.; Soukka, T. Photon Upconversion in a Molecular Lanthanide Complex in Anhydrous Solution at Room Temperature. ACS Photonics 2014, 1 (5), 394-397.

(7) Nonat, A.; Chan, C. F.; Liu, T.; Platas-Iglesias, C.; Liu, Z.; Wong, W.-T.; Wong, W.-K.; Wong, K.-L.; Charbonnière, L. J. Room Temperature Molecular up Conversion in Solution. Nat. Commun. 2016, 7, 11978.

(8) Souri, N.; Tian, P.; Platas-Iglesias, C.; Wong, K.-L.; Nonat, A.; Charbonnière, L. J. Upconverted Photosensitization of Tb Visible Emission by NIR Yb Excitation in Discrete Supramolecular Heteropolynuclear Complexes. J. Am. Chem. Soc. 2017, 139, 1456-1459.

(9) Charbonnière, L. J. Bringing Upconversion down to the Molecular Scale. Dalton Trans. 2018, Advance Article, doi: 10.1039/C7DT04737A.

(10) Nonat, A.; Liu, T.; Jeannin, O.; Camerel, F.; Charbonnière, L. J. Energy Transfer in Supramolecular Heteronuclear Lanthanide Dimers and Application to Fluoride Sensing in Water. Chem. Eur. J. 2018, 24, 3784-3792.

(11) Souri, N.; Tian, P.; Lecointre, A.; Lemaire, Z.; Chafaa, S.; Strub, J.-M.; Cianferani, S.; Elhabiri, M.; Platas-Iglesias, C.; Charbonniere, L. J. Step by Step Assembly of 
Polynuclear Lanthanide Complexes with a Phosphonated Bipyridine Ligand. Inorg. Chem. 2016, 55 (24), 12962-12974.

(12) Charbonnière, L.; Ziessel, R.; Guardigli, M.; Roda, A.; Sabbatini, N.; Cesario, M. Lanthanide Tags for Time-Resolved Luminescence Microscopy Displaying Improved Stability and Optical Properties. J. Am. Chem. Soc. 2001, 123 (10), 2436-2437.

(13) Nocton, G.; Nonat, A.; Gateau, C.; Mazzanti, M. Water Stability and Luminescence of Lanthanide Complexes of Tripodal Ligands Derived from 1,4,7-Triazacyclononane: Pyridinecarboxamide versus Pyridinecarboxylate Donors. Helv. Chim. Acta 2009, 92 (11), 2257-2273.

(14) Nonat, A.; Imbert, D.; Pécaut, J.; Giraud, M.; Mazzanti, M. Structural and Photophysical Studies of Highly Stable Lanthanide Complexes of Tripodal 8-Hydroxyquinolinate Ligands Based on 1,4,7-Triazacyclononane. Inorg. Chem. 2009, 48 (9), 4207-4218.

(15) Walton, J. W.; Di Bari, L.; Parker, D.; Pescitelli, G.; Puschmann, H.; Yufit, D. S. Structure, Resolution and Chiroptical Analysis of Stable Lanthanide Complexes of a Pyridylphenylphosphinate Triazacyclononane Ligand. Chem. Commun. 2011, 47 (45), 12289-12291.

(16) Starck, M.; Pal, R.; Parker, D. Structural Control of Cell Permeability with Highly Emissive Europium(III) Complexes Permits Different Microscopy Applications. Chem.Eur. J. 2016, 22 (2), 570-580.

(17) Frawley, A. T.; Pal, R.; Parker, D. Very Bright, Enantiopure Europium(III) Complexes Allow Time-Gated Chiral Contrast Imaging. Chem. Commun. 2016, 52 (91), 1334913352.

(18) W. Walton, J.; Bourdolle, A.; J. Butler, S.; Soulie, M.; Delbianco, M.; K. McMahon, B.; Pal, R.; Puschmann, H.; M. Zwier, J.; Lamarque, L.; Maury, O.; Andraud, C.; Parker, D. Very Bright Europium Complexes That Stain Cellular Mitochondria. Chem. Commun. 2013, 49 (16), 1600-1602.

(19) Butler, S. J.; Delbianco, M.; Lamarque, L.; McMahon, B. K.; Neil, E. R.; Pal, R.; Parker, D.; Walton, J. W.; Zwier, J. M. EuroTracker (R) Dyes: Design, Synthesis, Structure and Photophysical Properties of Very Bright Europium Complexes and Their Use in Bioassays and Cellular Optical Imaging. Dalton Trans. 2015, 44 (11), 4791-4803.

(20) Delbianco, M.; Sadovnikova, V.; Bourrier, E.; Mathis, G.; Lamarque, L.; Zwier, J. M.; Parker, D. Bright, Highly Water-Soluble Triazacyclononane Europium Complexes To Detect Ligand Binding with Time-Resolved FRET Microscopy. Angew. Chem.-Int. Ed. 2014, 53 (40), 10718-10722.

(21) Bui, A. T.; Grichine, A.; Brasselet, S.; Duperray, A.; Andraud, C.; Maury, O. Unexpected Efficiency of a Luminescent Samarium(III) Complex for Combined Visible and NearInfrared Biphotonic Microscopy. Chem. - Eur. J. 2015, 21 (49), 17757-17761.

(22) Elhabiri, M.; Abada, S.; Sy, M.; Nonat, A.; Choquet, P.; Esteban-Gómez, D.; Cassino, C.; Platas-Iglesias, C.; Botta, M.; Charbonnière, L. J. Importance of Outer-Sphere and Aggregation Phenomena in the Relaxation Properties of Phosphonated Gadolinium Complexes with Potential Applications as MRI Contrast Agents. Chem. - Eur. J. 2015, 21 (17), 6535-6546.

(23) Abada, S.; Lecointre, A.; Elhabiri, M.; Esteban-Gómez, D.; Platas-Iglesias, C.; Tallec, G.; Mazzanti, M.; Charbonnière, L. Highly Relaxing Gadolinium Based MRI Contrast Agents Responsive to Mg2+ Sensing. Chem. Commun. Camb. Engl. 2012, 48, 4085-4087. 
(24) Gottlieb, H. E.; Kotlyar, V.; Nudelman, A. NMR Chemical Shifts of Common Laboratory Solvents as Trace Impurities. J. Org. Chem. 1997, 62 (21), 7512-7515.

(25) Mikkelsen, K.; Nielsen, S. O. Acidity measurements with the glass electrode in $\mathrm{H}_{2} \mathrm{O}-\mathrm{D}_{2} \mathrm{O}$ mixtures. J. Phys. Chem. 1960, 64 (5), 632-637.

(26) Polášek, M.; Šedinová, M.; Kotek, J.; Vander Elst, L.; Muller, R. N.; Hermann, P.; Lukeš, I. Pyridine-N-Oxide Analogues of DOTA and Their Gadolinium(III) Complexes Endowed with a Fast Water Exchange on the Square-Antiprismatic Isomer. Inorg. Chem. 2009, 48 (2), 455-465.

(27) Altomare, A.; Burla, M. C.; Camalli, M.; Cascarano, G. L.; Giacovazzo, C.; Guagliardi, A.; Moliterni, A. G. G.; Polidori, G.; Spagna, R. SIR97: A New Tool for Crystal Structure Determination and Refinement. J. Appl. Crystallogr. 1999, 32, 115-119.

(28) Sheldrick, G. M. A Short History of SHELX. Acta Crystallogr. Sect. A 2008, 64, 112-122.

(29) Farrugia, L. J. WinGX Suite for Small-Molecule Single-Crystal Crystallography. J. Appl. Cryst. 1999, pp 837-839.

(30) Méthodes d'analyse Complexométriques Avec Les Titriplex; Merck E: Darmstadt, 1990.

(31) Molecular Fluorescence: Principles and Applications, 2nd Edition - Valeur, B. and Berberan-Santos, M. N. 2013, Weinheim: Wiley-VCH.

(32) Ishida, H.; Tobita, S.; Hasegawa, Y.; Katoh, R.; Nozaki, K. Recent Advances in Instrumentation for Absolute Emission Quantum Yield Measurements. Coord. Chem. Rev. 2010, 254 (21), 2449-2458.

(33) Weibel, N.; Charbonnière, L. J.; Guardigli, M.; Roda, A.; Ziessel, R. Engineering of Highly Luminescent Lanthanide Tags Suitable for Protein Labeling and Time-Resolved Luminescence Imaging. J. Am. Chem. Soc. 2004, 126 (15), 4888-4896.

(34) Benson, R. C.; Kues, H. A. Fluorescence Properties of Indocyanine Green as Related to Angiography. Phys. Med. Biol. 1978, 23 (1), 159-163.

(35) Gampp, H.; Maeder, M.; Meyer, C.; Zuberbuhler, A. Calculation of EquilibriumConstants from Multiwavelength Spectroscopic Data .1. Mathematical Considerations. Talanta 1985, 32 (2), 95-101.

(36) Lee, S.; Kim, H.; Yang, H.; Yoo, B.; Yoon, C. M. Synthesis of Diethyl Pyridin-2Ylphosphonates and Quinolin-2-Ylphosphonates by Deoxygenative Phosphorylation of the Corresponding N-Oxides. Bull. Korean Chem. Soc. 2014, 35 (7), 2155-2158.

(37) Comby, S.; Bünzli, J.-C. Chapter 235 Lanthanide Near-Infrared Luminescence in Molecular Probes and Devices. Handb. Phys. Chem. Rare Earths 2007, 37, 217-470.

(38) Longsworth, L. G. The mutual diffusion of light and heavy water. J. Phys. Chem. 1960, 64 (12), 1914-1917.

(39) Bui, A. T.; Beyler, M.; Grichine, A.; Duperray, A.; Mulatier, J.-C.; Guyot, Y.; Andraud, C.; Tripier, R.; Brasselet, S.; Maury, O. Near Infrared Two Photon Imaging Using a Bright Cationic $\mathrm{Yb}(\mathrm{III})$ Bioprobe Spontaneously Internalized into Live Cells. Chem. Commun. 2017, 53 (44), 6005-6008.

(40) D’Aléo, A.; Bourdolle, A.; Brustlein, S.; Fauquier, T.; Grichine, A.; Duperray, A.; Baldeck, P. L.; Andraud, C.; Brasselet, S.; Maury, O. Ytterbium-Based Bioprobes for Near-Infrared Two-Photon Scanning Laser Microscopy Imaging. Angew. Chem. Int. Ed. 2012, 51 (27), 6622-6625.

(41) Moore, E. G.; Xu, J.; Dodani, S. C.; Jocher, C. J.; D’Aléo, A.; Seitz, M.; Raymond, K. N. 1-Methyl-3-Hydroxy-Pyridin-2-One Complexes of Near Infra-Red Emitting Lanthanides: 
Efficient Sensitization of $\mathrm{Yb}(\mathrm{III})$ and $\mathrm{Nd}(\mathrm{III})$ in Aqueous Solution. Inorg. Chem. 2010, 49 (9), 4156-4166.

(42) Comby, S.; Imbert, D.; Vandevyver, C.; Bünzli, J.-C. G. A Novel Strategy for the Design of 8-Hydroxyquinolinate-Based Lanthanide Bioprobes That Emit in the Near Infrared Range. Chem. - Eur. J. 2007, 13 (3), 936-944.

(43) Werts, M. H. V.; Woudenberg, R. H.; Emmerink, P. G.; van Gassel, R.; Hofstraat, J. W.; Verhoeven, J. W. A Near-Infrared Luminescent Label Based on YbIII Ions and Its Application in a Fluoroimmunoassay. Angew. Chem. Int. Ed. 2000, 39 (24), 4542-4544.

(44) Zhang, T.; Zhu, X.; Cheng, C. C. W.; Kwok, W.-M.; Tam, H.-L.; Hao, J.; Kwong, D. W. J.; Wong, W.-K.; Wong, K.-L. Water-Soluble Mitochondria-Specific Ytterbium Complex with Impressive NIR Emission. J. Am. Chem. Soc. 2011, 133 (50), 20120-20122.

(45) Hu, J.-Y.; Ning, Y.; Meng, Y.-S.; Zhang, J.; Wu, Z.-Y.; Gao, S.; Zhang, J.-L. Highly Near-IR Emissive Ytterbium(III) Complexes with Unprecedented Quantum Yields. Chem. Sci. 2017, 8 (4), 2702-2709.

(46) Doffek, C.; Seitz, M. The Radiative Lifetime in Near-IR-Luminescent Ytterbium Cryptates: The Key to Extremely High Quantum Yields. Angew. Chem. Int. Ed Engl. 2015, 54 (33), 9719-9721.

(47) Ning, Y.; Liu, Y.-W.; Meng, Y.-S.; Zhang, J.-L. Design of Near-Infrared Luminescent Lanthanide Complexes Sensitive to Environmental Stimulus through Rationally Tuning the Secondary Coordination Sphere. Inorg. Chem. 2018, 57 (3), 1332-1341.

(48) Beeby, A.; Clarkson, I. M.; Dickins, R. S.; Faulkner, S.; Parker, D.; Royle, L.; de Sousa, A. S.; Williams, J. A. G.; Woods, M. Non-Radiative Deactivation of the Excited States of Europium, Terbium and Ytterbium Complexes by Proximate Energy-Matched OH, NH and $\mathrm{CH}$ Oscillators: An Improved Luminescence Method for Establishing Solution Hydration States. J. Chem. soc., Perkin Trans. 2. 1999, 493-504.

(49) Regueiro-Figueroa, M.; Bensenane, B.; Ruscsák, E.; Esteban-Gómez, D.; Charbonnière, L. J.; Tircsó, G.; Tóth, I.; de Blas, A.; Rodríguez-Blas, T.; Platas-Iglesias, C. Lanthanide Dota-like Complexes Containing a Picolinate Pendant: Structural Entry for the Design of Ln(III)-Based Luminescent Probes. Inorg. Chem. 2011, 50 (9), 4125-4141.

(50) Guanci, C.; Giovenzana, G.; Lattuada, L.; Platas-Iglesias, C.; Charbonnière, L. J. AMPED: A New Platform for Picolinate Based Luminescent Lanthanide Chelates. Dalton Trans. 2015, 44 (16), 7654-7661.

(51) Walton, J. W.; Carr, R.; Evans, N. H.; Funk, A. M.; Kenwright, A. M.; Parker, D.; Yufit, D. S.; Botta, M.; De Pinto, S.; Wong, K.-L. Isostructural Series of Nine-Coordinate Chiral Lanthanide Complexes Based on Triazacyclononane. Inorg. Chem. 2012, 51 (15), 80428056.

(52) Geraldes, C. F. G. C.; Alpoim, M. C.; Marques, M. P. M.; Sherry, A. D.; Singh, M. Nuclear Magnetic Resonance and Potentiometric Studies of the Protonation Scheme of a Triaza Triacetic Macrocycle and Its Complexes with Lanthanum and Lutetium. Inorg. Chem. 1985, 24 (23), 3876-3881.

(53) Nonat, A.; Gateau, C.; Fries, P. H.; Mazzanti, M. Lanthanide Complexes of a Picolinate Ligand Derived from 1,4,7-Triazacyclononane with Potential Application in Magnetic Resonance Imaging and Time-Resolved Luminescence Imaging. Chem.-Eur. J. 2006, 12 (27), 7133-7150.

(54) Evans, N. H.; Carr, R.; Delbianco, M.; Pal, R.; Yufit, D. S.; Parker, D. Complete Stereocontrol in the Synthesis of Macrocyclic Lanthanide Complexes: Direct Formation of 
Enantiopure Systems for Circularly Polarised Luminescence Applications. Dalton Trans. 2013, 42 (44), 15610. 